\title{
Antimicrobial Activity of Se-Nanoparticles from Bacterial Biotransformation
}

\author{
Meyli Claudia Escobar-Ramírez ${ }^{1}$, Araceli Castañeda-Ovando ${ }^{1, *}{ }^{\mathbb{D}}$, Emmanuel Pérez-Escalante ${ }^{1}(\mathbb{0}$, \\ Gabriela Mariana Rodríguez-Serrano ${ }^{2, *}$, Esther Ramírez-Moreno ${ }^{3}{ }^{\circledR}$, Aurora Quintero-Lira ${ }^{4}$, \\ Elizabeth Contreras-López ${ }^{1}$, Javier Añorve-Morga ${ }^{1}$, Judith Jaimez-Ordaz ${ }^{1}$ \\ and Luis Guillermo González-Olivares $1, *$ (i)
}

1 Área Académica de Química, Instituto de Ciencias Básicas e Ingeniería, Universidad Autónoma del Estado de Hidalgo, Mineral de la Reforma, Pachuca de Soto 42184, Hidalgo, Mexico; es409061@uaeh.edu.mx (M.C.E.-R.); emmanuel_perez@uaeh.edu.mx (E.P.-E.); elizac@uaeh.edu.mx (E.C.-L.); anorvej@uaeh.edu.mx (J.A.-M.); jjaimez@uaeh.edu.mx (J.J.-O.)

2 Departamento de Biotecnología, División de Ciencias Biológicas y de la Salud, Universidad Autónoma Metropolitana, Unidad Iztapalapa, Av. San Rafael Atlixco 186, Ciudad de México 09340, Mexico

check for updates

Citation: Escobar-Ramírez, M.C.; Castañeda-Ovando, A.;

Pérez-Escalante, E.;

Rodríguez-Serrano, G.M.;

Ramírez-Moreno, E.; Quintero-Lira,

A.; Contreras-López, E.;

Añorve-Morga, J.; Jaimez-Ordaz, J.;

González-Olivares, L.G.

Antimicrobial Activity of

Se-Nanoparticles from Bacterial

Biotransformation. Fermentation 2021,

7, 130. https://doi.org/10.3390/

fermentation7030130

Academic Editors: Vittorio Capozzi and Francesco Grieco

Received: 18 June 2021

Accepted: 22 July 2021

Published: 26 July 2021

Publisher's Note: MDPI stays neutral with regard to jurisdictional claims in published maps and institutional affiliations.

Copyright: (C) 2021 by the authors. Licensee MDPI, Basel, Switzerland. This article is an open access article distributed under the terms and conditions of the Creative Commons Attribution (CC BY) license (https:// creativecommons.org/licenses/by/ $4.0 /)$.
3 Área Académica de Nutrición, Instituto de Ciencias de la Salud, Universidad Autónoma del Estado de Hidalgo, Circuito Ex Hacienda, La Concepción S/N, Carretera Pachuca Actopan, San Agustín Tlaxiaca 42060, Hidalgo, Mexico; esther_ramirez@uaeh.edu.mx

4 Área Académica de Ingeniería Agroindustrial e Ingeniería en alimentos, Instituto de Ciencias Agropecuarias, Universidad Autónoma del Estado de Hidalgo, Av. Universidad km. 1, Ex-Hacienda de Aquetzalpa, Tulancingo 43600, Hidalgo, Mexico; aurora_quintero1489@uaeh.edu.mx

* Correspondence: ovandoa@uaeh.edu.mx (A.C.-O.); gmrs@xanum.uam.mx (G.M.R.-S.); lgonzales@uaeh.edu.mx (L.G.G.-O.); Tel.: +52-7717172000 (A.C.-O.); +52-5534442111 (L.G.G.-O.)

Abstract: Selenium nanoparticles (SeNPs) are gaining importance in the food and medical fields due to their antibacterial properties. The microbial inhibition of these kinds of particles has been tested in a wide range of Gram (+) and Gram (-) pathogenic bacteria. When SeNPs are synthesized by biological methods, they are called biogenic SeNPs, which have a negative charge caused by their interaction between surface and capping layer (bioorganic material), producing their high stability. This review is focused on SeNPs synthesis by bacteria and summarizes the main factors that influence their main characteristics: shape, size and surface charge, considering the bacteria growth conditions for their synthesis. The different mechanisms of antimicrobial activity are revised, and this review describes several biosynthesis hypotheses that have been proposed due to the fact that the biological mechanism of SeNP synthesis is not fully known.

Keywords: selenium-nanoparticle; bacteria; antibacterial activity; selenium biotransformation

\section{Introduction}

Nanoparticles (NPs) are defined as particles with one or more dimensions on the order of $100 \mathrm{~nm}$ or less [1,2] and are synthesized in different shapes and sizes through physical and chemical processes. Numerous investigations have demonstrated that NPs have remarkable properties in comparison to their bulk materials [3]. Furthermore, valuable micronutrients have been synthesized as NPs. In this sense, an important element in human nutrition, like selenium, has been prepared as nanoparticles, which have been called selenium nanoparticles (SeNPs).

In the last decade, many investigations have studied the SeNPs properties and have proven that SeNPs show high bioactivities with potential applications in several industries (i.e., food, medicine, or pharmacology) [4].

SeNPs have been synthesized by many processes; however, biotechnological methods have been one of the most important because the production of toxic species is avoided. 
In fact, it is known that many bacteria are capable of synthesizing SeNPs naturally through detoxification mechanisms [5-7], in which salts of selenite and selenate are reduced to non-toxic elemental selenium [8-10]. The antimicrobial activity of SeNPs has been studied by a great number of researchers, in which it has been found that SeNPs have a broad range of action against both pathogenic Gram-positive Gram-negative bacteria [4].

In this review, the biotransformation of inorganic to organic selenium is briefly explained to produce selenoamino acids and SeNPs; such processes have been explained independently in other reviews. However, it is necessary to gather this information for a better understanding of SeNPs observed in the culture media. However, there is already information on the biosynthesis of SeNPs by bacteria, a review of the factors that can affect the size, shape and surface charge of SeNPs that allows the standardization of synthesis processes still lacks in the literature. Mechanisms involved in the biosynthesis process of SeNPs are also discussed according to the data from numerous publications. The effect of SeNPs against pathogenic bacteria is critically evaluated. This review aims to provide a reference on the characteristics of SeNPs for researchers working in microbiology, with the purpose of highlighting future research opportunities and directions.

\section{Elemental Selenium as the Best Form for the Antimicrobial Activity}

Selenium (Se) is present in different organic and inorganic chemical forms that determine its bioavailability, function and toxicity [11] (Figure 1a). Inorganic Se can be found in the form of selenite and selenate, while the main organic forms of Se are selenoamino acids (selenomethionine and selenocysteine), selenopeptides and selenoproteins [12,13].

a

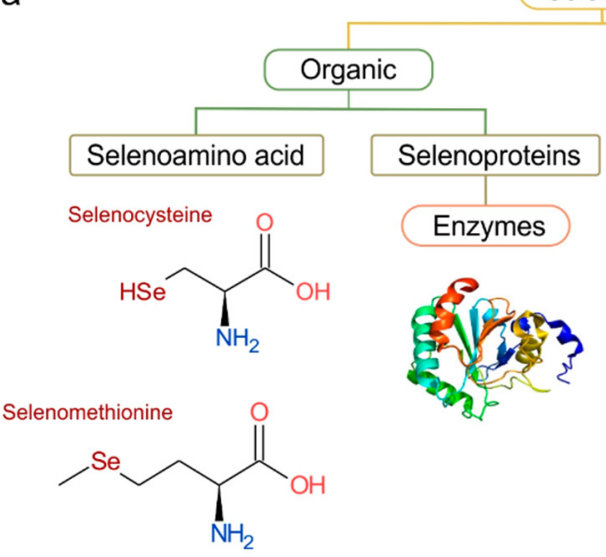

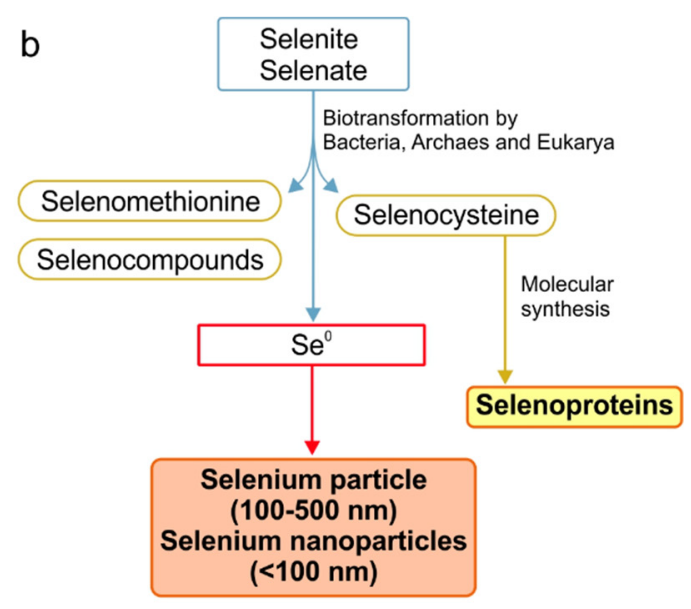

Figure 1. Selenium; (a) forms of organic and inorganic selenium; and (b) biotransformation of selenite and selenate in organic forms.

Selenocysteine is one of the most important biological forms. It is known as amino acid 21 and is the only amino acid present in the three domains of life: bacteria, archaea, and eukaryote. This amino acid is usually part of the active site of selenoproteins with enzymatic activity, due to is essential for the high catalytic activity of selenoproteins $[14,15]$. At the same time, selenoproteins, in bacteria and archaea, perform catabolic and oxidation-reduction functions [16,17]. Meanwhile, in eukaryotes, many of them act as oxido-reductases preventing and repairing the damage of cellular components, regulated by the redox state of proteins or by other redox functions [18]. This class of proteins play an important role in human health [19-23].

Meanwhile, inorganic Se is naturally found in four oxidation states, -2 (selenide, $\mathrm{Se}^{2-}$ ), 0 (elemental selenium, $\left.\mathrm{Se}^{0}\right),+4$ (selenite, $\mathrm{SeO}_{3}{ }^{2-}$ ) and +6 (selenate, $\mathrm{SeO}_{4}{ }^{2-}$ ), in which selenite and selenate show a greater toxic effect in humans than the other selenium species due to their high solubility and greater bioavailability [24,25]. However, even though $\mathrm{Se}^{0}$ is not toxic, it is not easily used by biological systems [26]. That is why some microorganisms biotransform selenite and selenate into selenomethionine, selenocysteine and volatile com- 
pounds. In addition, they could transform selenium species into $\mathrm{Se}^{0}$, which is commonly found as SeNPs (Figure 1b) [27-30]. Se ${ }^{0}$ possesses lower toxicity and higher biological bioavailability compared to its organic and inorganic forms $[11,17]$.

When $\mathrm{Se}^{0}$ is found as a nanoparticle, it has certain antimicrobial properties due to its size and charge, which is dependent on the bioorganic compounds that interact with the SeNPs surface to form a charged negative capping. Therefore, they are attracted by the cell, causing a rupture of the cell wall and allowing the free transport of SeNPs, which may produce reactive oxygen species (ROS) [31-33].

That is why SeNPs are emerging as promising nanomaterials in the health field due to their action against pathogenic microorganisms [34-36]. ROS produced within the cell by induction of metal ions or nanoparticles cause the oxidation of glutathione, thus suppressing the antioxidant defence mechanism of pathogenic bacteria against these reactive species [31,33]. In such a way, released $\mathrm{Se}^{0}$ interacts with cell structures (for example, proteins, membranes, DNA), causing cell damage or death [37]. On the other hand, with the high surface/volume ratio of SeNPs, a greater area of interaction with pathogenic bacteria is achieved, increasing ROS production [38].

\section{Bacterial SeNPs Synthesis}

Many bacteria could biosynthesize SeNPs through the detoxification mechanism under anaerobic or aerobic conditions [8,39-41]. These bacteria could reduce selenite and selenate oxyanions, either in the form of non-toxic $\mathrm{Se}^{0}$ or methylated Se species by a cellular detoxification mechanism that maintains redox potential as part of its respiratory chain of electron transfer [42-44]. Microorganisms biosynthesize SeNPs, while Se oxyanions are reduced and could be accumulated in different forms, such as intracellular, extracellular or bonded to the membrane.

The first study about biosynthesized SeNPs was observed in selenite detoxification by Escherichia coli [45]. After this study, several reports of different species of both Gramnegative and Gram-positive bacteria, using detoxification processes to produce SeNPs, were published (Table 1). These include bacteria such as Acinetobacter sp., Burkholderia sp., Duganella sp., Klebsiella sp., Microbacterium sp., Pseudomonas sp., Rhodospirillum sp., Stenotrophomonas sp., Shewanella sp., Staphylococcus sp., Thauera sp., Bacillus sp. and recently it has also been reported that lactic acid bacteria (LAB), such as Lactobacillus, Bifidobacterium and Streptococcus are capable of synthesizing SeNPs.

Table 1. Gram-negative and Gram-positive bacteria used for synthesis of SeNPs.

\begin{tabular}{|c|c|c|c|c|c|c|}
\hline Gram-Negative Bacteria & Shape & Size $(\mathrm{nm})$ & [Se] & Culture Conditions & Location & Ref. \\
\hline Acinetobacter sp. SW30 & Spherical/rod & $78-126$ & $0.3-2 \mathrm{mM} \mathrm{Na}_{2} \mathrm{SeO}_{3}$ & Aerobic, $30^{\circ} \mathrm{C}, 24 \mathrm{~h}$ & NS & [49] \\
\hline Agrobacterium & Spherical & $185-190$ & $40 \mathrm{mg} / \mathrm{L} \mathrm{Na}_{2} \mathrm{SeO}_{4}$ & Aerobic, $28^{\circ} \mathrm{C}, 8 \mathrm{~h}$ & Ex & {$[50]$} \\
\hline Alcaligenes faecalis & Spherical & 273.8 & $5 \mathrm{mM} \mathrm{Na}_{2} \mathrm{SeO}_{3}$ & Aerobic, $30^{\circ} \mathrm{C}, 36 \mathrm{~h}$ & Ex & {$[10]$} \\
\hline Azoarcus sp. & Spherical & $\begin{array}{c}123 \\
78-84 /\end{array}$ & $1 \mathrm{mM} \mathrm{Na}_{2} \mathrm{SeO}_{3}$ & Aerobic, $30^{\circ} \mathrm{C}, 7$ days & Ex & [25] \\
\hline Azospirillum brasilense Sp245 & Spherical & $\begin{array}{l}40-50 \\
/ 25-28\end{array}$ & $10 / 25 / 50 \mathrm{mM} \mathrm{Na}_{2} \mathrm{SeO}_{3}$ & Aerobic, $31-32{ }^{\circ} \mathrm{C}, 24 \mathrm{~h}$ & Ex & [27] \\
\hline Azospirillum brasilense Sp7 and Sp245 & Spherical & $50-400$ & $0.3 \mathrm{mM} \mathrm{Na}_{2} \mathrm{SeO}_{3}$ & Aerobic, $31-32{ }^{\circ} \mathrm{C}, 7$ days & In & [51] \\
\hline Burkholderia fungorum 95 & Spherical & 170 & $2 \mathrm{mM} \mathrm{Na}_{2} \mathrm{SeO}_{3}$ & Anaerobic, $27^{\circ} \mathrm{C}, 24 / 48 / 72 \mathrm{~h}$ & In and Ex & [44] \\
\hline Burkholderia fungorum DBT1 & Spherical & 200 & $2 \mathrm{mM} \mathrm{Na}_{2} \mathrm{SeO}_{3}$ & Anaerobic, $27^{\circ} \mathrm{C}, 24 / 48 / 72 \mathrm{~h}$ & In and Ext & [44] \\
\hline Comamonas testosteroni & Spherical & $100-200$ & $1-20 \mathrm{mM} \mathrm{Na}_{2} \mathrm{SeO}_{3}$ & Aerobic, $28^{\circ} \mathrm{C}, 24 \mathrm{~h}$ & In & [52] \\
\hline Duganella sp. & Spherical & $140-200$ & $40 \mathrm{mg} / \mathrm{L} \mathrm{Na}_{2} \mathrm{SeO}_{4}$ & Aerobic, $28^{\circ} \mathrm{C}, 8 \mathrm{~h}$ & $\begin{array}{l}\text { Ex and } \\
\text { cell bound }\end{array}$ & {$[50]$} \\
\hline E. coli $\mathrm{K}-12$ & Spherical & $24-122$ & $4 \mathrm{mM} \mathrm{H}_{2} \mathrm{SeO}_{3}$ & Condition not specified, $48 \mathrm{~h}$ & Ex & [53] \\
\hline E. coli & Spherical & 120 & $2 \mathrm{mM} \mathrm{Na}_{2} \mathrm{SeO}_{3}$ & Aerobic, $37^{\circ} \mathrm{C}, 72 \mathrm{~h}$ & NS & [40] \\
\hline Klebsiella pneumonia & Spherical & $90-320$ & $200 \mathrm{mg} / \mathrm{L} \mathrm{SeCl}_{4}$ & Aerobic, $37^{\circ} \mathrm{C}, 24 \mathrm{~h}$ & In & [54] \\
\hline Lysinibacillus sp. NOSK & Spherical & $\begin{array}{c}150 / \\
130 / 145\end{array}$ & $1 \mathrm{mM} \mathrm{Na}_{2} \mathrm{SeO}_{3}$ & Aerobic, $37^{\circ} \mathrm{C}, 24 / 48 / 72 \mathrm{~h}$ & NS & [36] \\
\hline $\begin{array}{c}\text { Methicillin-resistance Staphylococcus } \\
\text { aureus }\end{array}$ & Spherical/rod & 121 & $2 \mathrm{mM} \mathrm{Na}_{2} \mathrm{SeO}_{3}$ & Aerobic, $37^{\circ} \mathrm{C}, 72 \mathrm{~h}$ & NS & [40] \\
\hline Pantoea agglomerans & Spherical & $30-300$ & $1 \mathrm{mM} \mathrm{Na}_{2} \mathrm{SeO}_{3}$ & Aerobic, $25^{\circ} \mathrm{C}, 15 / 20 / 24 \mathrm{~h}$ & In & [55] \\
\hline Proteus mirabilis YC0801 & Spherical & 178.3 & $5 \mathrm{mM} \mathrm{Na}_{2} \mathrm{SeO}_{3}$ & Aerobic, $30^{\circ} \mathrm{C}, 24-36 \mathrm{~h}$ & Ex & [56] \\
\hline Providencia vermicola BGRW & Hexagonal & 28 & $1 \mathrm{mM} \mathrm{SeO}_{2}$ & Aerobic, $37^{\circ} \mathrm{C}, 24 \mathrm{~h}$ & In and Ex & [57] \\
\hline Pseudomonas aeruginosa & Spherical & 140 & $2 \mathrm{mM} \mathrm{Na}_{2} \mathrm{SeO}_{3}$ & Aerobic, $37^{\circ} \mathrm{C}, 72 \mathrm{~h}$ & Ex & [58] \\
\hline Pseudomonas aeruginosa & Spherical & 171 & $2 \mathrm{mM} \mathrm{Na}_{2} \mathrm{SeO}_{3}$ & Aerobic, $37^{\circ} \mathrm{C}, 72 \mathrm{~h}$ & NS & [40] \\
\hline Pseudomonas alcaliphila & Spherical & $50-500$ & $0.1 \mathrm{mM} \mathrm{Na}_{2} \mathrm{SeO}_{3}$ & Anaerobic, $28^{\circ} \mathrm{C}, 48 \mathrm{~h}$ & In & [59] \\
\hline Pseudomonas putida & Spherical & $100-500$ & $1 \mathrm{mM} \mathrm{Na}_{2} \mathrm{SeO}_{3}$ & Aerobic, $30^{\circ} \mathrm{C}, 24 \mathrm{~h}$ & In and Ex & [60] \\
\hline
\end{tabular}


Table 1. Cont.

\begin{tabular}{|c|c|c|c|c|c|c|}
\hline Gram-Negative Bacteria & Shape & Size $(\mathrm{nm})$ & [Se] & Culture Conditions & Location & Ref. \\
\hline Rhodopseudomonas palustris strain $\mathrm{N}$ & Spherical & $80-200$ & $1 \mathrm{mM} \mathrm{Na}_{2} \mathrm{SeO}_{3}$ & Anaerobic, $30^{\circ} \mathrm{C}, 8$ days & Ex & [61] \\
\hline Selenihalanaerobacter shriftii & Spherical & $\sim 300$ & $3 \mathrm{mM} \mathrm{Na}_{2} \mathrm{SeO}_{3}$ & Anaerobic, $25^{\circ} \mathrm{C}, 72 \mathrm{~h}$ & In and Ex & {$[62]$} \\
\hline Shewanella sp. & Spherical & $<103$ & $0.01-1 \mathrm{mM} \mathrm{Na}_{2} \mathrm{SeO}_{3}$ & $30^{\circ} \mathrm{C}, 72 \mathrm{~h}$ & In & [63] \\
\hline Staphylococcus aureus & $\begin{array}{l}\text { Spherical } \\
\text { Spherical/ }\end{array}$ & 180 & $2 \mathrm{mM} \mathrm{Na}_{2} \mathrm{SeO}_{3}$ & Aerobic, $37^{\circ} \mathrm{C}, 72 \mathrm{~h}$ & NS & [40] \\
\hline Stenotrophomonas bentonitica & $\begin{array}{l}\text { Trigonal } \\
\text { Se crystals }\end{array}$ & $100-400$ & $2 \mathrm{mM} \mathrm{Na}_{2} \mathrm{SeO}_{3}$ & Aerobic, $48-145 \mathrm{~h}$ & In and Ex & [48] \\
\hline Stenotrophomonas maltophilia & Spherical & $\leq 270$ & $\begin{array}{l}0.5 \mathrm{mM} \mathrm{Na}_{2} \mathrm{SeO}_{4} \\
0.5 \mathrm{mM} \mathrm{Na}_{2} \mathrm{SeO}_{3}\end{array}$ & Aerobic, room temp, $48 \mathrm{~h}$ & $\begin{array}{l}\text { Near } \\
\text { periphery of } \\
\text { cell wall }\end{array}$ & [64] \\
\hline Stenotrophomonas maltophilia & Spherical & 170.6 & $2 \mathrm{mM} \mathrm{Na}_{2} \mathrm{SeO}_{3}$ & Anaerobic, $27^{\circ} \mathrm{C}, 24 \mathrm{~h}$ & Ex & [65] \\
\hline Stenotrophomonas maltophilia SeITE02 & Spherical & $\begin{array}{c}221 / \\
345 / 357\end{array}$ & $0.5 \mathrm{mM} \mathrm{Na}_{2} \mathrm{SeO}_{3}$ & Aerobic, $27^{\circ} \mathrm{C}, 6 / 24 / 48 \mathrm{~h}$ & NS & {$[38]$} \\
\hline Stenotrophomonas maltophilia SeITE02 & Spherical & $100-300$ & $0.5 \mathrm{mM} \mathrm{Na}_{2} \mathrm{SeO}_{3}$ & Aerobic, $27^{\circ} \mathrm{C}, 48 \mathrm{~h}$ & Ex & [66] \\
\hline $\begin{array}{l}\text { Streptomyces minutiscleroticus } \\
\text { M10A62 }\end{array}$ & Spherical & $100-250$ & $2 \mathrm{mM} \mathrm{Na}_{2} \mathrm{SeO}_{3}$ & Aerobic, room temperature, $72 \mathrm{~h}$ & Ex & {$[67]$} \\
\hline Sulfurospirillum barnesii & Spherical & $\sim 300$ & $3 \mathrm{mM} \mathrm{Na}_{2} \mathrm{SeO}_{3}$ & Anaerobic, $25^{\circ} \mathrm{C}, 72 \mathrm{~h}$ & In and Ex & {$[62]$} \\
\hline Synechococcus leopoliensis & Spherical & $174-348$ & $5 \mathrm{mM} \mathrm{Na}_{2} \mathrm{SeO}_{3}$ & Aerobic, $22{ }^{\circ} \mathrm{C}, 9$ days & $\begin{array}{l}\text { On cell } \\
\text { surface }\end{array}$ & {$[68]$} \\
\hline Thauera selenatis & Spherical & 150 & $10 \mathrm{mM}$ Selenate & Anaerobic, condition not specified & In & [29] \\
\hline Vibrio natriegen & $\begin{array}{l}\text { Spherical } \\
\text { Spherical, }\end{array}$ & $100-400$ & $1 \mathrm{mM} \mathrm{Na}_{2} \mathrm{SeO}_{3}$ & Aerobic, $30^{\circ} \mathrm{C}, 24 \mathrm{~h}$ & In & [69] \\
\hline Zooglea ramigera & $\begin{array}{l}\text { Trigonal } \\
\text { selenium } \\
\text { nanorods }\end{array}$ & $30-150$ & $3 \mathrm{mM} \mathrm{Na}_{2} \mathrm{SeO}_{3}$ & Aerobic, $30^{\circ} \mathrm{C}, 48 \mathrm{~h}$ & Ex & {$[70]$} \\
\hline \multicolumn{7}{|c|}{ Gram positive bacteria } \\
\hline Bacillus cereus & Spherical & $150-200$ & $2 \mathrm{mM} \mathrm{Na}_{2} \mathrm{SeO}_{3}$ & Aerobic, $37^{\circ} \mathrm{C}, 24 \mathrm{~h}$ & $\begin{array}{l}\text { In and cell } \\
\text { bound }\end{array}$ & [71] \\
\hline Bacillus cereus & Spherical & $400-600$ & $100 \mathrm{mg} / \mathrm{mL} \mathrm{Na}_{2} \mathrm{SeO}_{3}$ & Condition not specified, $30^{\circ} \mathrm{C}, 24 \mathrm{~h}$ & NS & [72] \\
\hline Bacillus licheniformis ATCC 10716 & Spherical & $50-80$ & $1 \mathrm{mM} \mathrm{SeO}_{2}$ & Aerobic, $37^{\circ} \mathrm{C}, 24 \mathrm{~h}$ & $\begin{array}{c}\text { In, on the } \\
\text { bacterial cell }\end{array}$ & {$[73]$} \\
\hline Bacillus licheniformis JS2 & Spherical & 120 & $1.8 \mathrm{mM} \mathrm{Na}_{2} \mathrm{SeO}_{3}$ & Aerobic, $37^{\circ} \mathrm{C}, 15 \mathrm{~h}$ & In & [74] \\
\hline Bacillus megaterium & Spherical & 200 & $0.05-2 \mathrm{mM} \mathrm{Na}_{2} \mathrm{SeO}_{3}$ & Aerobic, $37^{\circ} \mathrm{C}, 80 \mathrm{~h}$ & Ex & [75] \\
\hline Bacillus mycoides & Spherical & $50-400$ & $2 \mathrm{mM} \mathrm{Na}_{2} \mathrm{SeO}_{3}$ & Aerobic, $28^{\circ} \mathrm{C}, 48 \mathrm{~h}$ & Ex & [76] \\
\hline Bacillus mycoides & Spherical & 160 & $2 \mathrm{mM} \mathrm{Na}_{2} \mathrm{SeO}_{3}$ & Aerobic, $27^{\circ} \mathrm{C}, 6 \mathrm{~h}$ & NS & {$[65]$} \\
\hline Bacillus mycoides SelTE01 & Spherical & $<100$ & $100 \mathrm{mM} \mathrm{Na}_{2} \mathrm{SeO}_{3}$ & Aerobic, $27^{\circ} \mathrm{C}, 24 \mathrm{~h}$ & NS & [42] \\
\hline Bacillus safensis JG-B5T & Spherical & $85-450$ & $2.5 \mathrm{mM} \mathrm{Na}_{2} \mathrm{SeO}_{3}$ & Anaerobic, $30^{\circ} \mathrm{C}, 24 \mathrm{~h}$ & Ex & {$[47]$} \\
\hline Bacillus selenitireducens & Spherical & 300 & $3 \mathrm{mM} \mathrm{Na}_{2} \mathrm{SeO}_{3}$ & Aerobic, $25^{\circ} \mathrm{C}, 3$ days & In and Ex & [62] \\
\hline Bacillus sp. & Spherical & $31-335$ & $6.4 \mathrm{mM} \mathrm{Na}_{2} \mathrm{SeO}_{3}$ & Aerobic, $33^{\circ} \mathrm{C}, 72 \mathrm{~h}$ & Ex & [41] \\
\hline Bacillus sp. & Oval & $209-748$ & $30 \mathrm{mM} \mathrm{Na}_{2} \mathrm{SeO}_{3}$ & Condition not specified, $37^{\circ} \mathrm{C}$ & NS & {$[1]$} \\
\hline Bacillus sp. B2 & Spherical & $20-50$ & $5 \mathrm{mM} \mathrm{Na}_{2} \mathrm{SeO}_{3}$ & $\begin{array}{l}\text { Condition not specified. room } \\
\text { temperature, } 24 \mathrm{~h}\end{array}$ & Ex & {$[46]$} \\
\hline Bacillus sp. MSh-1 & Spherical & $80-220$ & $1.26 \mathrm{mM} \mathrm{SeO}_{2}$ & Aerobic, $30^{\circ} \mathrm{C}, 14 \mathrm{~h}$ & In & [77] \\
\hline Bacillus subtilis & Spherical & $50-400$ & $4 \mathrm{mM} \mathrm{Na}_{2} \mathrm{SeO}_{3}$ & Aerobic, $35^{\circ} \mathrm{C}, 48 \mathrm{~h}$ & Ex & [78] \\
\hline Bifidobacterium sp. & Spherical & $400-500$ & $200 \mathrm{mg} / \mathrm{L} \mathrm{NaHSeO}_{3}$ & Aerobic, $37^{\circ} \mathrm{C}, 36-48 \mathrm{~h}$ & NS & [79] \\
\hline Enterococcus faecalis & Spherical & 29-195 & $0.19-2.97 \mathrm{mM} \mathrm{Na}_{2} \mathrm{SeO}_{3}$ & Aerobic, $37-42{ }^{\circ} \mathrm{C}, 24$ and $48 \mathrm{~h}$ & Ex & {$[80]$} \\
\hline Lactobacillus acidophilus & Spherical & $10-20$ & $4 \mathrm{mM} \mathrm{Na}_{2} \mathrm{SeO}_{3}$ & Aerobic, $35^{\circ} \mathrm{C}, 48 \mathrm{~h}$ & NS & [81] \\
\hline Lactobacillus acidophilus & Spherical & $2-15$ & $15 \mathrm{mM} \mathrm{Na}_{2} \mathrm{SeO}_{3}$ & Aerobic, $37^{\circ} \mathrm{C}, 48 \mathrm{~h}$ & Ex & [39] \\
\hline Lactobacillus acidophilus CRL 636 & Spherical & 176 & $25 \mathrm{mM} \mathrm{Na}_{2} \mathrm{SeO}_{3}$ & Aerobic, $37^{\circ} \mathrm{C} 24 \mathrm{~h}$ & In & [82] \\
\hline Lactobacillus brevis & - & $>250$ & $2.54 \mathrm{mM} \mathrm{SeO}_{2}$ & Condition not specified, $37^{\circ} \mathrm{C}, 72 \mathrm{~h}$ & In & [83] \\
\hline Lactobacillus bulgaricus CRL 656 & Spherical & 160 & $25 \mathrm{mM} \mathrm{Na}_{2} \mathrm{SeO}_{3}$ & Aerobic, $37^{\circ} \mathrm{C} 24 \mathrm{~h}$ & In & [82] \\
\hline Lactobacillus casei 393 & Spherical & $50-80$ & $1.2 \mathrm{mM} \mathrm{Na}_{2} \mathrm{SeO}_{3}$ & Aerobic, $37^{\circ} \mathrm{C}, 24 \mathrm{~h}$ & In & [84] \\
\hline Lactobacillus lactis NZ9000 & Spherical & 143 & $0.6 \mathrm{mM} \mathrm{Na}_{2} \mathrm{SeO}_{3}$ & Anaerobic, $30^{\circ} \mathrm{C}, 48 \mathrm{~h}$ & NS & {$[44]$} \\
\hline Lactobacillus plantarum & Spherical & $60-80$ & $4 \mathrm{mM} \mathrm{Na}_{2} \mathrm{SeO}_{3}$ & Aerobic, $37^{\circ} \mathrm{C}, 36-48 \mathrm{~h}$ & NS & [81] \\
\hline Lactobacillus reuteri CRL 1101 & Spherical & 130 & $25 \mathrm{mM} \mathrm{Na}_{2} \mathrm{SeO}_{3}$ & Aerobic, $37^{\circ} \mathrm{C}, 24 \mathrm{~h}$ & In & [82] \\
\hline Lactobacillus rhamnosus & Spherical & $60-80$ & $4 \mathrm{mM} \mathrm{Na}_{2} \mathrm{SeO}_{3}$ & Aerobic, $37^{\circ} \mathrm{C}, 36-48 \mathrm{~h}$ & NS & {$[81]$} \\
\hline Lactobacillus sp. & Spherical & $100-200$ & $200 \mathrm{mg} / \mathrm{L} \mathrm{NaHSeO}_{3}$ & Aerobic, $37^{\circ} \mathrm{C}, 36-48 \mathrm{~h}$ & NS & [79] \\
\hline Streptococcus thermophilus & Spherical & $50-100$ & $200 \mathrm{mg} / \mathrm{L} \mathrm{NaHSeO}_{3}$ & Aerobic, $37^{\circ} \mathrm{C}, 36-48 \mathrm{~h}$ & NS & [79] \\
\hline
\end{tabular}

NS: not specified, Ex: Extracellular, In: Intracellular.

As research progresses, bacteria of different genera with the ability to synthesize SeNPs, continue to be found. Recently, it has been reported by different authors that three Gram-positive bacteria of the genus Bacillus sp. have the ability to synthesize spherical SeNPs located extracellularly with variable particle sizes $(20-50,85-450,31-335 \mathrm{~nm})[41,46,47]$. Likewise, Gram-negative bacteria such as Stenotrophomonas bentonitica [48], Azospirillum brasilense Sp245 [27] and the Lysinibacillus sp. NOSK [36] were also reported as microorganisms capable of synthesizing SeNPs from inorganic selenium salts. These studies reveal that the synthesis of SeNPs is carried out by a wide range of bacteria, which belong to different bacterial phyla, and that the synthesis mechanisms could share homologies between them. 


\subsection{Microbial Growth and Its Relation with SeNPs Synthesis}

After Se reduction, SeNPs are accumulated in bacterial cells during the exponential growth phase and are secreted to the medium in the stationary phase $[25,69]$. It is common to find a selenium deposit per cell, which could be seen as a dense sphere in the cytoplasmic compartment. During the stationary phase, cultures begin to turn red, and selenium nanospheres are observed in the medium. This is because they are associated with the cell surface $[43,55,62,65,80]$. That is why diverse studies have been focused on the identification of produced SeNPs and their relation to the bacterial growth phase of specific species.

Different bacteria have shown that selenite reduction and $\mathrm{Se}^{0}$ formation is associated with microbial growth (Table 2). For example, with one millimole of selenite in the media, $V$. natriegens consumes approximately $70 \%$ of selenium during the exponential phase, significantly increasing the biomass amount $\left(5 \times 10^{6}\right.$ to $\left.5 \times 10^{8} \mathrm{CFU} / \mathrm{mL}\right)$ [69]. In contrast, in cultures of Shewanella sp. HN-41 [63], Synechococcus leopoliensis [68] Shewanella oneidensis MR-1 [85], Pseudomonas putida KT2440 [60] and B. fungorum DBT1 [43], selenite reduction begins in the middle of the exponential growth phase; meanwhile, Rhodospirillum rubrum reduction is presented at the end of this phase [8].

Table 2. Selenite reduction detection in the growth phase.

\begin{tabular}{|c|c|c|c|c|}
\hline Bacteria & $\begin{array}{l}\text { Selenite } \\
\text { mM }\end{array}$ & $\begin{array}{l}\text { Reduction of } \\
\mathrm{Na}_{2} \mathrm{SeO}_{3}\end{array}$ & Selenite Reduction Detection (Time) & Reference \\
\hline Alcaligenes faecalis Se03 & 5 & $>73 \%$ & $\begin{array}{l}\text { End-exponential growth phase and stretched } \\
\text { into the stationary phase ( } 18 \text { and } 42 \mathrm{~h}) .\end{array}$ & [10] \\
\hline Alcaligenes faecalis $\mathrm{Se} 03$ & 1 & $>90 \%$ & Mid-exponential growth phase (12 and $24 \mathrm{~h})$ & [10] \\
\hline Azoarcus sp. CIB & 8 & - & Stationary growth phase $(48 \mathrm{~h})$ & [25] \\
\hline Bacillus mycoides Sel TE01 & 0.5 & $50 \%$ & Early-exponential growth phase $(5 \mathrm{~h})$ & [76] \\
\hline Bacillus mycoides Sel TE01 & 2 & $25 \%$ & Early-exponential growth phase $(5 \mathrm{~h})$ & [76] \\
\hline Burkholderia fungorum DBT1 & 2 & $79 \%$ of $5 \mathrm{mM}$ & Mid-exponential growth phase $(24 \mathrm{~h})$ & {$[43]$} \\
\hline Lactococcus lactis NZ9000 & 0.6 & $100 \%$ & Stationary growth phase $(48 \mathrm{~h})$ & {$[44]$} \\
\hline Proteus mirabilis YC801 & 1 & $81 \%$ & Mid-exponential growth phase (12 and $24 \mathrm{~h}$ ) & [56] \\
\hline Proteus mirabilis YC802 & 5 & $59 \%$ & End-exponential growth phase $(24 \mathrm{~h})$ & [56] \\
\hline Pseudomonas moraviensis & 10 & - & Stationary growth est $(12 \mathrm{~h})$ & [26] \\
\hline Pseudomonas putida KT2440 & 1 & - & Mid-exponential growth phase $(12 \mathrm{~h})$ & {$[60]$} \\
\hline Rhodopseudomonas palustris $\mathrm{N}$ & 8 & - & Stationary growth est $(50 \mathrm{~h})$ & [61] \\
\hline Rhodospirillum rubrum & 1.5 & - & Late-exponential growth phase $(70 \mathrm{~h})$ & [8] \\
\hline Shewanella oneidensis MR-1 & 0.5 & $82 \%$ & Mid-exponential growth phase (12 h) & [85] \\
\hline Shewanella sp. HN-41 & 1 & - & Mid-exponential growth phase $(12 \mathrm{~h})$ & {$[63]$} \\
\hline Stenotrophomonas maltophilia SelTE02 & 0.5 & $100 \%$ & Early-exponential growth phase $(80 \mathrm{~h})$ & [66] \\
\hline Stenotrophomonas maltophilia SelTE02 & 2 & $86 \%$ & Stationary growth phase $(92 \mathrm{~h})$ & [66] \\
\hline Synechococcus leopoliensis & 5 & - & Mid-exponential growth phase $(24 \mathrm{~h})$ & {$[68]$} \\
\hline Vibrio natriegens & 100 & - & Early-exponential growth phase $(3 \mathrm{~h})$ & [69] \\
\hline
\end{tabular}

Nevertheless, some reports have indicated that during the stationary phase, a reduction of selenite is presented. For example, in bacteria such as Pseudomonas moraviensis, selenite reduction $(10 \mathrm{mM})$ begins in the stationary phase after nine hours of incubation, at a consumption rate of $0.27 \mathrm{mmol} / \mathrm{h}$, and total selenite is consumed after $48 \mathrm{~h}$ [26]. Similarly, the consumption of selenite and formation of SeNPs in anaerobic cultures of Azoarcus sp. CIB is observed only in the stationary phase of growth [25], but it has also been shown that during the exponential growth phase, bacteria resist excess selenite through their own detoxification mechanism. In fact, it has been observed that this mechanism is energydependent and only when cells are highly energized (in the exponential growth phase) selenite could be secreted from the cell. On the contrary, cells depleted in energy (in the stationary phase) produce SeNPs by reduction of selenite, keeping it in the cytoplasm [25].

Based on the reported information, reduction of selenite occurs mainly in the exponential and stationary growth phases $[60,61,68]$. However, it is known that selenite concentration used in cell cultures determines if the reduction of selenite to $\mathrm{Se}^{0}$ is carried 
out in the exponential or stationary phase $[76,85]$. In this sense, when S. maltophilia SeITE02 grows in a culture medium supplemented with $0.5 \mathrm{mM}$ of selenite, Se is consumed at $100 \%$, mainly during the exponential phase. However, when this microorganism is cultured with $2.0 \mathrm{mM}$ selenite, less than $10 \%$ is reduced in the exponential phase, and $86 \%$ of total selenite is reduced, mainly during the stationary phase [66].

In the same way, Alcaligenes faecalis Se03 showed different behaviours in the presence of two different concentrations of selenite. In cultures with an initial concentration of selenite of $1 \mathrm{mM}$, more than $90 \%$ of $\mathrm{SeO}_{3}{ }^{2-}$ depletion is observed during the exponential growth phase; on the contrary, in the presence of $5 \mathrm{mM}$ selenite, the greatest reduction $(>73 \%$ ) occurred at the end of the exponential growth phase and was extended to the stationary phase [10].

Other bacteria, such as Proteus mirabilis YC801, reduce selenite more effectively when there are smaller concentrations of salt. When $1.0 \mathrm{mM}$ selenite is used, more than $81 \%$ is reduced during the exponential growth phase; meanwhile, when the bacteria are exposed to $5 \mathrm{mM}$ selenite, $59 \%$ of selenite, reduction occurs at the end of the exponential growth phase and into the stationary phase while the remaining selenite is depleted in the stationary phase [56]. This phenomenon is also observed in Bacillus mycoides Sel TE01 [76] and Shewanella oneidensis MR-1 [85].

Although studies indicate that the selenite reduction process could happen at the same time as microbial growth, $\mathrm{Se}^{0}$ is produced after a certain amount of selenite is consumed. It was observed that the initial concentration of $\mathrm{Na}_{2} \mathrm{SeO}_{3}$ decreases by $16.3 \%$ when Proteus mirabilis is grown in the presence of a $1.0 \mathrm{mM}$ concentration of the salt, and $5.8 \%$ is transformed into detectable $\mathrm{Se}^{0}[56]$. B. mycoides shows delays of 6 and $9 \mathrm{~h}$ between selenite depletion and $\mathrm{Se}^{0}$ detection when cultured in a growth medium supplemented with $0.5 \mathrm{mM}$ and $2.0 \mathrm{mM} \mathrm{SeO}_{3}{ }^{2-}$, respectively [76]. This behaviour has also been reported in bacteria such as S. maltophilia [66] and A. faecalis [10]. Because of the delays in $\mathrm{Se}^{0}$ formation and sodium selenite consumption, it has been suggested that the conversion could be carried out by the formation of an intermediate form of reduced Se, such as organic selenide (RSeR) which appears before its final reduction to $\mathrm{Se}^{0}[10,86]$.

\subsection{General Mechanism of SeNPs Synthesis}

There are diverse mechanisms used by bacteria to reduce selenate and selenite, which may include one or several metabolic pathways and enzymes, as well as other proteins, which have been documented in different reviews and publications [87-89]. Recently, Tan et al. [90] reported a mechanism of selenate reduction to $\mathrm{Se}^{0}$, different from those studies that showed a reduction of selenate to selenite in the periplasm or SeNPs on the cell surface of Comamonas testosterone S44, an aerobic bacterium that reduces both selenate and selenite to $\mathrm{Se}^{0}$. However, it is considered that the general mechanism of SeNPs synthesis is divided into a process that includes two steps: (i) formation of $\mathrm{Se}^{0}$, carried out by reduction of selenate to selenite and then reduction of selenite to insoluble $\mathrm{Se}^{0}$, and (ii) formation of SeNPs including assembly and exportation out of the cell $[44,56,66,91]$.

\subsection{1. $\mathrm{Se}^{0}$ Formation: Selenate Reduction to Selenite}

Primarily, the reduction of selenate to selenite is an enzymatic process. It is carried out by either a soluble or membrane-bound selenate reductase [92,93], which are part of the iron-sulfur molybdoenzymes family and comprise three subunits with molybdenum as a co-factor, located in the periplasm or in the cytoplasmic membrane. The product of selenate reductase (selenite) is always released in the periplasm or outside the cytoplasmic membrane in Gram-negative and Gram-positive bacteria, respectively (Table 3).

Currently, the selenate reductases identified through genomic and enzymatic approaches are present in two Gram-negative bacteria (Thauera selenatis, Enterobacter cloacae SLD1a-1, E. coli), and one Gram-positive bacteria (Bacillus selenatarsenatis SF-1). In the case of Thauera selenatis, the reduction process of selenate to selenite is known to take place in the periplasmic compartment by a soluble periplasmic protein $[94,95]$, that consists of three 
subunits: a molybdenum cofactor (SerA), a subunit containing iron-sulfur clusters (SerB) and a cytochrome $\mathrm{b}$ (SerC) subunit. The genes encoding these subunits were identified as $\operatorname{ser} A$, serB and $\operatorname{ser} C$, respectively, and $\operatorname{ser} D$, which encodes a system-specific chaperone [96]. In the periplasm, selenate reductase reduces selenate to selenite by accepting electrons from the periplasmic c-type cytochromes involving both quinol-cytochrome $\mathrm{C}$ oxidoreductase (QCR) and quinol dehydrogenase (QDH) [97].

This reductase is different from that of Enterobacter cloacae SLD1a-1, which is a membrane-bound insoluble protein that contains molybdenum, heme, and non-heme iron [93]. The active site of this enzyme is oriented to the periplasm, and its assembly depends on a twin-arginine translocation (TAT) [98]. In contrast to T. selenatis, the selenate reductase complex of E. cloacae is an insoluble protein bound to the cytoplasmic membrane, and it is not free in the periplasm. The genes encoding the selenate reductase complex remain unknown. Likewise, in E. coli, two operons have been proposed, ygfKLMN [92] and $y n f E F G H$ [99], that encode the enzyme selenate reductase (molybdoenzyme) and a sulfate- $\mathrm{ABC}$ transport complex, which is encoded by the cysAWTP operon [28]. However, selenate reduction by E. coli has not been characterized.

On the other hand, the possible differences between selenate reductases in Gramnegative and Gram-positive bacteria are still unclear. At present, the Gram-positive bacteria Bacillus selenatarsenatis has been identified to have a unique operon $(\mathrm{s} r \mathrm{~d} B C A)$ that encodes a membrane-bound selenate reductase complex; this complex couples quinone oxidation with selenate reduction [100].

Table 3. Conditions involved in the reduction of selenate to selenite in anaerobic bacteria.

\begin{tabular}{|c|c|c|c|c|}
\hline Bacteria & Compartment & Selenate Reductase & $\begin{array}{l}\text { Additional Requirements for } \\
\text { Selenate Reduction Pathway }\end{array}$ & Ref. \\
\hline Thauera selenatis & Periplasm & $\begin{array}{l}\text { Trimeric molybdoenzyme: SerA, } \\
\text { catalytic subunit; SerB, iron-sulfur } \\
\text { protein and SerC heme b protein. } \\
\text { ser } A B C D \text { operon. }\end{array}$ & & {$[29,96,101]$} \\
\hline $\begin{array}{l}\text { Enterobacter cloacae } \\
\text { SLD1a-1 }\end{array}$ & Membrane-bound & $\begin{array}{l}\text { Trimeric molybdoenzyme: } \\
\text { molybdenum, heme, and } \\
\text { non-heme iron }\end{array}$ & $\begin{array}{l}\text { Global transcriptional regulatory } \\
\text { gene fnr; tat } A B C \text { translocation } \\
\text { pathway: menaquinone } \\
\text { biosynthetic pathway menFDHBCE }\end{array}$ & {$[93,98,99,102,103]$} \\
\hline E. coli & Periplasm & $\begin{array}{l}\text { Molybdoenzyme: YgfK, YgfN and } \\
\text { YgfM protein. ygfKLMN operon. }\end{array}$ & & [92] \\
\hline E. coli & $\begin{array}{l}\text { Associated with the } \\
\text { periplasmic face of the } \\
\text { cytoplasmic membrane }\end{array}$ & $\begin{array}{l}\text { Molybdo-enzyme: YnfE and YnfF } \\
\text { as putative Tat-targeted selenate } \\
\text { reductases. ynfEFGH operon }\end{array}$ & $\begin{array}{l}\text { TAT translocase apparatus and } \\
\text { TorD-like chaperone }\end{array}$ & {$[104]$} \\
\hline
\end{tabular}

\subsection{2. $\mathrm{Se}^{0}$ Formation: Selenite Reduction to $\mathrm{Se}^{0}$}

Once selenite is released in the bacteria periplasm after reduction, bacteria cannot utilize selenite as the unique electron acceptor, and it is further reduced to $\mathrm{Se}^{0}$ by selenite reductases [87]. Several enzymes' systems have been proposed to explain selenite reduction by bacteria, such as nitrite reductase $[105,106]$, sulfite reductase [10], fumarate reductase [85,107] and Painter-type reactions [108]. This last is characterized by containing thiol or glutathione reductase $[109,110]$. Unlike selenate reductases, selenite reductases are located in the cytoplasm or the cytoplasmic membrane and, in some cases, in the periplasm, which depends on the bacteria type. For example, in some bacteria, such as T. selenatis, E. coli, Enterobacter cloacae, Bacillus selenitireducens, Bacillus mycoides SeITE01, Proteus mirabilis YC801 and Stenotrophomonas maltophilia SeITE02, reduction of selenite to $\mathrm{Se}^{0}$ is developed in the cytoplasm while selenite reduction by Shewanella oneidensis MR-1 is carried out in the periplasm (Table 4). 
Table 4. Enzymes involved in the reduction of selenite to $\mathrm{Se}^{0}$.

\begin{tabular}{|c|c|c|c|c|}
\hline Bacteria & Growing Conditions & Cell Compartment & $\begin{array}{l}\text { Enzymes and Biomolecules Involved in } \\
\text { Selenite Reduction }\end{array}$ & Ref. \\
\hline Thauera selenatis & Anaerobic & Cytoplasm & Periplasmic nitrite reductases or glutathione & {$[29,101,105]$} \\
\hline $\begin{array}{l}\text { Enterobacter cloacae } \\
\text { SLD1a-1 }\end{array}$ & Anaerobic & Cytoplasm & Nitrite reductases or glutathione & {$[101,111]$} \\
\hline $\begin{array}{c}\text { E. coli } \\
\text { E. cloacae Z0206 }\end{array}$ & $\begin{array}{l}\text { Anaerobic } \\
\text { Aerobic }\end{array}$ & $\begin{array}{l}\text { Cytoplasm } \\
\text { Cytoplasm }\end{array}$ & $\begin{array}{l}\text { Glutathione, thioredoxin reductase } \\
\text { Fumarate reductase, glutathione }\end{array}$ & $\begin{array}{c}{[43,50]} \\
{[63]}\end{array}$ \\
\hline Alcaligenes faecalis $\mathrm{Se} 03$ & Anaerobic & Cytoplasm & $\begin{array}{l}\text { Sulfite reductase, thioredoxin reductase, } \\
\text { NADPH or NADH as electron donors }\end{array}$ & {$[10]$} \\
\hline Alishewanella sp. WH16-1 & Aerobic & - & Selenite reductase called CsrF & [112] \\
\hline $\begin{array}{l}\text { Burkholderia fungorum } \\
\text { DBT1 }\end{array}$ & Aerobic & Cytoplasm & Glutathione, cytoplasmic reductases & {$[43]$} \\
\hline Bacillus mycoides SeITE01 & Aerobic & Cytoplasm & $\begin{array}{l}\text { Sulfhydryl groups on peptide thiols, membrane } \\
\text { reductases, bacilithiols }\end{array}$ & [76] \\
\hline Bacillu safensis JG B5T & Aerobic & Outside the cells & $\begin{array}{c}\text { Succinate dehydrogenase } \\
\text { (membrane-associated proteins) }\end{array}$ & [47] \\
\hline Bacillus subtilis & Aerobic & - & Thioredoxin reductase & [113] \\
\hline Ochrobactrum sp. MPV1 & Aerobic & Cytoplasm & Glutathione & [114] \\
\hline Proteus mirabilis YC 801 & Aerobic & Cytoplasm & Thioredoxin reductase and fumarate reductase & [56] \\
\hline $\begin{array}{l}\text { Pseudomonas } \\
\text { seleniipraecipitans }\end{array}$ & Aerobic & - & Thioredoxin reductase & [115] \\
\hline Rhizobium sullae & Aerobic & - & Nitrite reductases & [106] \\
\hline Rhodobacter sphaeroides & Aerobic and anaerobic & Cytoplasm & Glutathione $^{\mathrm{a}}$ & [116] \\
\hline Rhodospirillum rubrum & Anaerobic & Cytoplasm & Glutathione & [109] \\
\hline Shewanella oneidensis MR-1 & Anaerobic & Periplasm & Fumarate reductase FccA & [85] \\
\hline
\end{tabular}

a Selenite entry into the cytoplasm is mediated by a polyol transporter.

The mechanism of selenite transport across the plasmatic membrane to the cytoplasm is still unknown. In addition, the reduction of Se oxyanions does not always occur because this step is not mandatory when the reduction is carried out extracellularly. In Rhodobacter sphaeroides (reduces selenite but not selenate), selenite is transferred to cytoplasm presumably through a polyol transporter [116], and the DedA protein has been reported to be involved in selenite uptake [117]. Whereas, in E. coli, selenite is transported by a sulfate permease, although significant uptake has been observed after the suppression of the $A B C$ transporter, indicating that there is at least one more selenite uptake system. Likewise, in T. selenatis, it has been suggested that selenite is formed in the periplasmic compartment and is transported across the plasmatic membrane to the cytoplasm via a currently unknown sulfate transporter [53]. When selenite reaches the cytoplasm, the reduction of selenite to $\mathrm{Se}^{0}$ could be catalysed by periplasmic nitrite reductases [105] or performed involving glutathione [29].

Painter type reaction. In some bacteria, it has been shown that the reduction of selenite to $\mathrm{Se}^{0}$ can be carried out by reactions with thiol groups of proteins/peptides in the so-called "Painter-type" reaction. Currently, the Painter-type reaction is considered one of the basic reactions in microbial detoxification of Se oxyanions. In this mechanism, the selenite easily reacts with glutathione (GSH) to produce selenodiglutathione (GS-Se-SG), which is further reduced by the enzyme NADPH-glutathione reductase (GR) or thioredoxin reductase (TR), leading to the formation of glutathione selenopersulfide (GS-Se ${ }^{-}$. Glutathione selenopersulfide is an unstable intermediate and undergoes a hydrolysis reaction to form $\mathrm{Se}^{0}$ and reduced GSH (Figure 2) $[28,29,109]$.

In bacteria such as Rhodobacter sphaeroides, Rhodobacter rubrum (which only reduce selenite but not selenate) and Ochrobactrum sp. MPV1 [109,114,116], it has been suggested that glutathione is also used in selenite reduction to $\mathrm{Se}^{0}$. However, in the bacteria Burkholderia fungorum DBTI and Burkholderia fungorum 95, in addition to using glutathione, they also use cytoplasmic reductases that accept electrons from NADH and NADPH, free thiols and protein thiol groups [43].

Despite the fact that GSH is considered the main candidate to reduce selenite, some bacteria have other alternative mechanisms. For example, under aerobic conditions, SeNPs synthesis of Bacillus mycoides SeITE01 could be extracellular or intracellular. Therefore, it is 
proposed that selenite ions are enzymatically reduced to $\mathrm{Se}^{0}$ through three different ways: (i) redox reactions by proteins released from bacterial cells, (ii) selenite reactions directly with sulfhydryl groups in released peptide thiols by Bacillus cells and (iii) membrane and intracellular reductases synthesize low molecular weight thiols such as bacillithiols [76]. In this sense, bacillithiol synthesized by bacteria could be analogous to enzymes found in glutathione-containing bacterial species, such as bacilliredoxins [118].

Reductases. In Stenotrophomonas sp. EGS12 selenite reduction is carried out synergistically by two reductases: nitrite reductase and thiol-mediated reductase [119]. A similar mechanism was reported in Enterobacter cloacae SLD1a-1, in which, under anaerobic conditions, selenite reduction depends on a nitrite reductase or intracellular glutathione [101,111]. On the other hand, under aerobic conditions, Song et al. [107] observed that selenite reduction is carried out mainly through fumarate reductase instead of glutathione in E. cloacae Z0206. In contrast, Shewanella oneidensis uses fumarate reductase (FccA) for selenite reduction to $\mathrm{Se}^{0}$ and this process is carried out in periplasm [85].

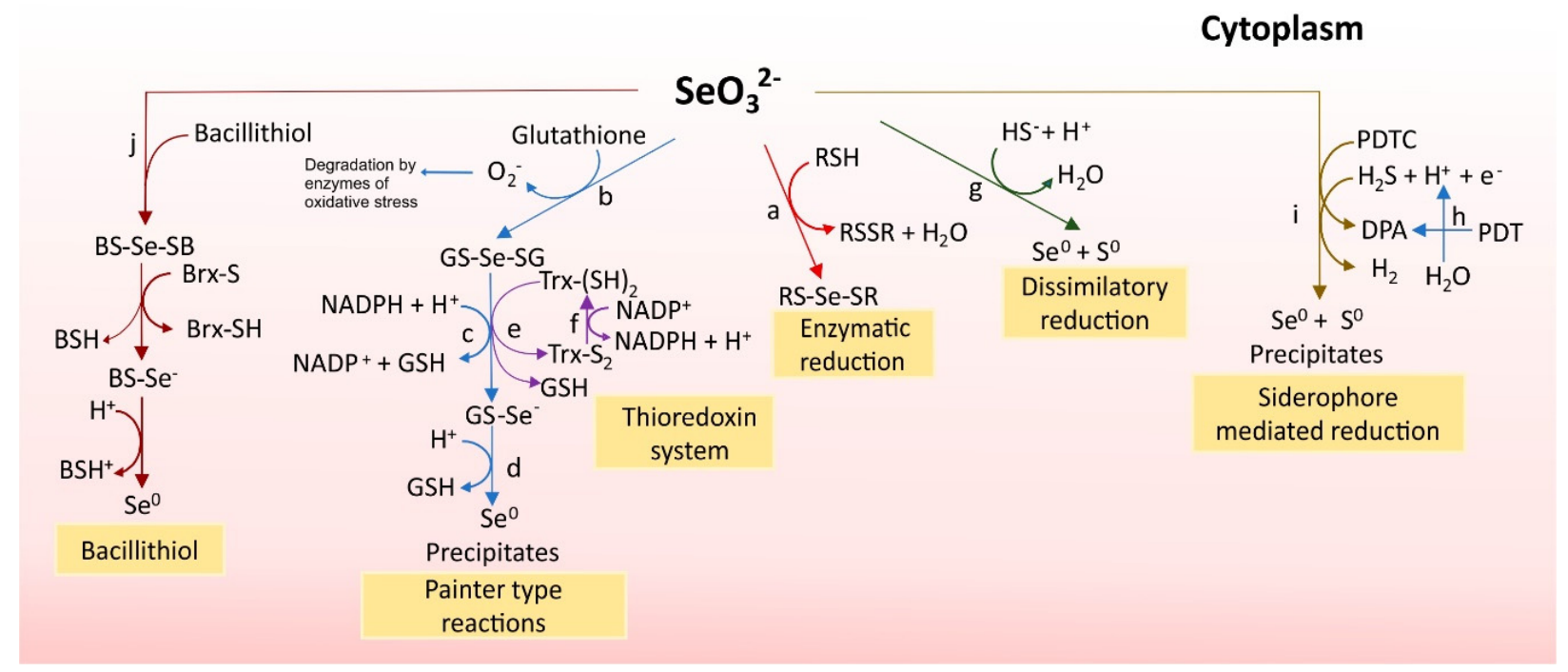

Figure 2. Biochemical pathways for the biological reduction of Se. (a) Enzymatic reduction, (b) methylation, (c) dissimilatory reduction concomitant with sulfate reduction, (d) painter-type reactions with the thiols of proteins as well as glutathione, $(\mathbf{e}, \mathbf{f})$ thioredoxin system, $(\mathbf{g})$ dissimilatory reduction, $(\mathbf{h}, \mathbf{i})$ chemical reaction with the siderophore-iron-specific $\left(\mathrm{Fe}^{3+}\right)$ and (j) pathway analogous to those observed with GSH that involve Brx-like proteins. Image based on Zannoni et al. [120] and Helmann et al. [121].

Different bacteria, Alcaligenes faecalis Se03, for example, grown under aerobic conditions, involve enzymes such as sulfite reductase and thioredoxin reductase in reduction processes using NADPH or NADH as electron donors [10]. Similarly, in Proteus mirabilis YC801, selenite reduction is catalyzed by thioredoxin reductase and fumarate reductase instead of glutathione, nitrite reductases and sulfite reductases [56]. In addition, when sodium selenite is in the medium, thioredoxin reductase is used to reduce selenite to $\mathrm{Se}^{0}$ by Bacillus subtilis [113], Escherichia coli [116] and Pseudomonas seleniipraecipitans [115].

\subsubsection{SeNPs Formation}

Se atoms formed in bacteria during the reduction of selenite form $\mathrm{Se}^{0}$, which grows in a spherical shape either intracellularly or extracellularly. Electron microscopy images of bacterial cultures and microbial communities have shown Se nanospheres in the cytoplasm, on the cell surface, and in the medium (Figure 3) $[10,62,77,89,101]$.

Intracellular formation of selenium. When the reduction of selenite to $\mathrm{Se}^{0}$ is carried out in the cytoplasm, the formation of $\mathrm{Se}^{0}$ atoms and subsequently the assembly of Se nanospheres also occurs in the cytoplasm. In order to avoid the accumulation of Se nanospheres and associated necrosis, the cell must have an export mechanism for the trans- 
port of Se nanospheres formed intracellularly [91]. Se nanospheres formed by T. selenatis into the cytoplasm are transported out the cell. The process involves the reduction of selenite to $\mathrm{Se}^{0}$, which is bound to a SefA protein for developing a Se nanosphere, which is further released by lysis or transported across the membrane outside the cell by an unknown mechanism $[29,122]$. SefA, with approximately $95 \mathrm{kDa}$ of mass, is regulated and secreted in response to the increase of selenite concentration in the medium. In vitro assays have shown that this protein plays a stabilizing role for Se nanospheres during selenite reduction [29]. Thus, there is a large number of unspecific proteins, which interact only with intracellular SeNPs and eventually lead to high colloidal stability [47].

Extracellular formation of selenium. Once selenite is reduced to $\mathrm{Se}^{0}$ in the cytoplasm, it is transported (as a foreign entity) across the membrane outside the cell by an unknown export mechanism. Then, $\mathrm{Se}^{0}$ nuclei are assembled outside the cell into Se spheres, through some Ostwald-type mechanism, which has been described for some bacteria in recent years such as Azospirillum brasilense [27], Stenotrophomonas maltophilia SeITE02 [66], Burkholderia fungorum DBT1, Burkholderia fungorum 95 [43] and Bacillus mycoides SelTE01 [76].

\subsubsection{SeNPs Formation: Assembly}

The final stage of SeNPs formation is their assembly after the reduction of Se oxyanions. This mechanism has also been little studied and is not entirely clear. Some authors suggested that SeNPs formation could imply an Ostwald maturation mechanism, in which small particles coalesce to generate larger ones due to their high superficial energy $[76,109]$. Other authors propose that molecules such as proteins, polysaccharides or extracellular polymeric substances (EPS), which are observed on the SeNP surface, act as a cover or capping agent in the formed nanoparticle at the final stage of the synthesis (Figure 3) $[29,44,53,84,123]$.

The capping has different functions according to the type of molecule on the SeNPs' surface: (i) control of the size distribution of SeNPs, (ii) nanoparticles' stability, (iii) reduction of toxicity and (iv) improvement of antimicrobial activity. For example, RarA protein, which is a metalloid reductase, has the highest number of peptides with a strong affinity for SeNPs, conferring their stability [124]. Another example is the propanol-preferring alcohol dehydrogenase (AdhP) that is implied in the control of the size distribution of SeNPs [53].

In the case of intracellular SeNPs extracted from Lactobacillus sp., studies using FTIR spectroscopy have shown a higher proportion of proteins than polysaccharides capping SeNPs $[44,84,125,126]$. These authors proposed that proteins with a high concentration of charged amino acids could be related to the formation process and the stabilization of SeNPs in bacteria. Meanwhile, the minor stability of extracellular SeNPs is due to a low concentration of extracellular protein bound to SeNPs and/or proteins with low affinity to Se [47]. 


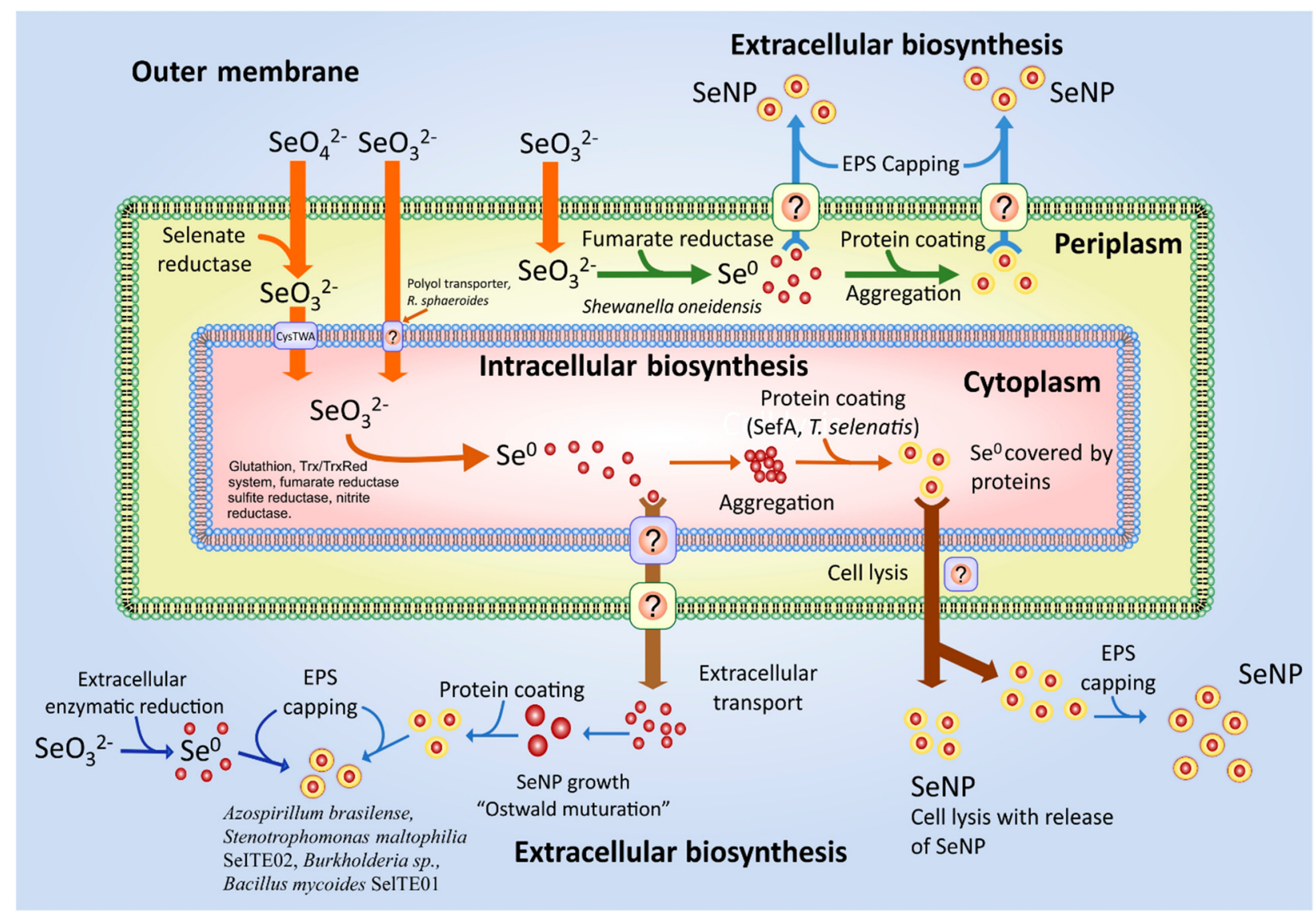

Figure 3. Mechanism of selenite reduction to selenium nanoparticle. Image based on Jain et al. [126] and Sinharoy et al. [127].

\section{SeNPs Morphology and the Antimicrobial Activity}

In recent years, SeNPs have attracted attention due to their unique antimicrobial properties. They are considered a novel and potential alternative to standard antibiotics, as they have great potential against increasing multidrug resistance in pathogenic bacteria and fungi. The development and synthesis of these nanomaterials for their use as antimicrobials depend directly on some physical and chemical properties, such as concentration, zeta-potential, surface area, size and shape.

\subsection{SeNPs Concentration}

One of the most important physico-chemical parameters that affect the antimicrobial activity of SeNPs is their concentration. This property is directly related to microbial species due to their different characteristics of the cell surface. Cremonini et al. [65] indicated that the antimicrobial activity of SeNPs synthesized by Stenotrophomonas maltophilia and Bacillus mycoides inhibited the growth of clinical isolates of Pseudomonas aeruginosa at concentrations from 8 to $512 \mathrm{mg} / \mathrm{mL}$ but did not inhibit Candida albicans and Candida parapsilosis species. On the other hand, El-Deeb et al. [57] indicated that $10 \mu \mathrm{g}$ of SeNPs synthesized by Providencia vermicola BGRW had a strong inhibitory effect on the growth of four Gram-positive pathogens (S. aureus, B. Cereus, methicillin-resistant S. aureus and S. agalactiae) and E. coli. However, most Gram-negative bacteria (P. aeruginosa, Enterobacter sp., Enterococcus sp., Proteus mirabilis, Klebsiella sp., Salmonella enteritidis and Stenotrophomonas maltophilia) and Candida albicans are not inhibited at this concentration. Greeshma and Mahesh [1] indicated that $400 \mu \mathrm{g}$ of SeNPs produced by Bacillus showed an antibacterial effect on St. mutans, B. cereus, E. coli and C. albicans, but it was in the last two that the greatest inhibition was observed. 
Likewise, several authors have shown that antibacterial activity depends on the amount of SeNPs. For example, rising from 10 to $15 \mu \mathrm{g}$, the inhibition of 4 Gram-positive pathogenic bacteria $(14 \%$ S. aureus, $17 \%$ B. cereus, $24 \%$ S. agalactaie, $31 \%$ E. coli and $37 \%$ methicillin-resistant $S$. aureus) was significantly increased. On the contrary, when a concentration between 2.5 and $10 \mu \mathrm{g} / \mathrm{mL}$ of SeNPs is used, there is no antibacterial effect in any of the strains tested in the study by El-Deeb et al. [57]. Comparably, Alam et al. [39] demonstrated complete inhibition in the growth of 5 strains (E. coli, S. aureus, B. subtilis, P. aeruginosa, K. pneumonia) when 1 to $10 \mu \mathrm{g} / \mathrm{mL}$ of SeNPs were used, this concentration was calculated as the minimum inhibitory (MIC90) after 4 to $6 \mathrm{~h}$ of contact with the bacteria, but by doubling it, and leaving it in contact for $6 \mathrm{~h}$, the SeNPs act as a bactericide.

Similarly, Bharathi et al. [46] reported that antibacterial activity on Gram-positive bacteria (Staphylococcus aureus) and Gram-negative bacteria (Pseudomonas aeruginosa, E. coli, Klebsiella pneumoniae) is higher when a concentration of 10 at $100 \mu \mathrm{g}$ of SeNPs was used. Additionally, these researchers also demonstrated that the bactericidal concentration is specific for each bacterium. They tested the MIC $(8 \mu \mathrm{g}$ SeNP/200 $\mu \mathrm{L})$ and the minimum bactericidal concentration $(\mathrm{CMB}, 8 \mu \mathrm{g} \mathrm{SeNP} / 100 \mu \mathrm{L}$ ) and observed that $P$. aeruginosa showed greater sensitivity to SeNPs compared to E. coli, K. pneumoniae and $S$ aureus.

In the same way, Zhang et al. [33] found that $500 \mathrm{mg} / \mathrm{L}$ of SeNPs got a greater antibacterial activity on Gram-negative bacteria than on Gram-positive ones. In this sense, some authors have established stabilized parameters for nanoparticles through the interaction with biological molecules (polysaccharides and proteins) to decrease minimum inhibitory concentrations and increase their activity spectrum. B. subtilis was treated with SeNPs stabilized with bovine serum albumin (BSA), D-glucose and soluble starch. Scanning electron microscopy (SEM) analysis revealed morphological changes in bacterial cells treated with all three types of SeNPs compared to untreated B. subtilis cells. A considerable reduction in the amount of viable B. subtilis was observed in soluble starch-SeNPs, in which cells were shrunken and fragmented, and a polydispersity of cell size was observed. This effect was contrary to that observed in untreated B. subtilis [128].

However, in a study carried out with SeNPs stabilized with chitosan, it was shown that antimicrobial activity was effective only against Gram-positive bacteria (Streptococcus sanguinis, Staphylococcus aureus and Enterococcus faecalis) but not against Gram-negative bacteria (Pseudomonas aeruginosa, Salmonella typhimurium, and E. coli), using a MIC in a range of 0.068 to $0.274 \mathrm{mg} / \mathrm{mL}$. Moreover, it was observed that MIC decreases when SeNPs are stabilized with polysaccharides. In addition, the results revealed that MIC of $0.274 \mathrm{mg} / \mathrm{mL}$ had a greater bactericidal effect with Gram-positive bacteria after $6 \mathrm{~h}$ of contact [129].

\subsection{Coating Surface and Charge}

The surface charge of nanoparticles is characterized by the zeta-potential, which is another factor that plays an important role in antimicrobial activity since the interaction between nanoparticles and the cell membrane is based on electrostatic adhesion [38]. This interaction is observed because bacteria have specific characteristics that explain their behaviour in contact with SeNPs. For example, both Gram-positive and Gram-negative bacteria have a negatively charged surface [130-133], which could attract positively charged nanoparticles [32].

Specifically, SeNPs have shown better antimicrobial effectiveness against Grampositive bacteria than Gram-negative bacteria $[129,134,135]$. However, the mechanisms for the different effects of SeNPs against bacteria are not entirely clear. Galić et al. [136] designed SeNPs coated with polyvinylpyrrolidone (PVP-SeNPs), poly-L-lysine (PLL-SeNPs) and polyacrylic acid (PAA-SeNPs) to obtain neutral, positively and negatively charged SeNPs, respectively. Antibacterial action of all the studied SeNPs was observed against Gram-positive S. aureus ( $24 \mathrm{~h} \mathrm{MBC} 25-50 \mathrm{mg} \mathrm{Se} / \mathrm{L}$ ), but not against E. coli and S. cerevisiae. In a similar investigation, Rangrazi et al. [129] showed that positively charged chitosan SeNPs have good antimicrobial activity against Gram-positive bacteria (Strepto- 
coccus sanguinis, Staphylococcus aureus and Enterococcus faecalis), but no bactericidal effect was found against Gram-negative bacteria (Pseudomonas aeruginosa, Salmonella typhimurium, and Escherichia coli).

In the same way, Filipović et al. [137] stabilized SeNPs with bovine serum albumin (SeNPs-BSA), chitosan (Chit) and glucose (Gluc). -BSA and SeNPs-Chit showed positive potentials (SeNPs-BSA, $+27 \pm 3$; SeNPs-Chit, $+24 \pm 1$ ) and the SeNPs-Gluc showed negative potential $(-45 \pm 1)$. These were tested to inhibit the growth of four Gram-positive bacteria (Staphylococcus aureus, Enterococcus faecalis, Bacillus subtilis and Kocuria rhizophila) and four Gram-negative bacteria (Escherichia coli, Salmonella abony, Klebsiella pneumoniae, and Pseudomonas aeruginosa). They observed that zeta-positive SeNPs showed significantly greater antibacterial activity than negatively charged SeNPs, with the exception of those in contact with Escherichia coli. This bacterium was inhibited by negatively charged SeNPs at a lower concentration $(290 \mu \mathrm{g} / \mathrm{mL})$ than SeNPs-BSA, which had a positive charge $(400 \mu \mathrm{g} / \mathrm{mL})$. On the other hand, Cremonini et al. [65] produced two types of SeNPs, which were synthesized by B. mycoides SeITE01 and S. maltophilia SeITE02. Additionally, a chemically synthesized SeNP was tested. The three SeNPs generated negative zeta-potential between -70 and $-80 \mathrm{mV}$; however, the antimicrobial activity against clinical isolates of $P$. aeruginosa was greater when they used biogenic SeNPs than those chemically synthesized. The authors attributed these differences to the presence of a bacterial protein layer that covers the surface of the biogenic particles and which is related to the zeta-potential.

Several studies attribute the antimicrobial activity of biogenic SeNPs to the presence of a natural covering or capping on their surface, such as polysaccharides, proteins and lipids $[4,44,84,123]$. The presence of this coating provides them with natural stability, which makes them highly stable, mainly for clinical treatments. Studies on SeNP coating functions have shown that in addition to particles stability, they also affect their zeta-potential.

Recently, Tugarova et al. [27] reported that SeNPs synthesized by A. brasilense Sp7 cells are covered by a bioorganic layer that comprises proteins, polysaccharides and lipids, with a significant proportion of ionized carboxylic groups. Sidechains of some amino acid residues and carboxylated polysaccharides typically form these last groups, but they are also responsible for the negative SeNPs' zeta-potentials. This has also been suggested by other researchers, such as Lampis et al. [66], who identified an organic or biomolecular layer composed of carbohydrates, lipids and proteins around the negatively charged SeNPs produced by Stenotrophomonas maltophilia SeITE02.

Likewise, Khoei et al. [43] also observed that SeNPs zeta-potential generated by Burkholderia fungorum 95 and Burkholderia fungorum DBT1 was related to the presence of exopolysaccharides as a component of the organic layer around the SeNPs, suggesting that exopolysaccharides composed of carbohydrates, proteins, and humic-like substances may govern SeNPs' zeta-potential produced by microorganisms. Studies on SeNPs and their charge, measured by zeta-potential, are carried out to establish their stability and antimicrobial effectiveness; that is why the research field is open to expanding the knowledge of this physicochemical relationship.

\subsection{Size and Shape}

One of the most important physicochemical properties that affect antimicrobial activity is size. Typically, smaller nanoparticles have relatively higher stability and antimicrobial activity than bigger ones. This is because smaller nanoparticles present a greater surface area, which provides superior interaction and intracellular penetration $[34,114,138]$. In particular, SeNPs with a smaller size than $100 \mathrm{~nm}$ biosynthesized by Stenotrophomonas maltophilia SeITE02 demonstrated a better antimicrobial effect to inhibit pathogens (S. aureus, E. coli and $P$. aeruginosa) compared to those with a size between 100 and $400 \mathrm{~nm}$ [114].

Similarly, SeNPs obtained extracellularly from B. licheniformis with a size between 10 and $50 \mathrm{~nm}$ exhibit an antimicrobial effect in the inhibition of foodborne pathogens (B. cereus, E. faecalis, S. aureus, E. coli O157: H7, S. typhimurium, S. enteritidis) at concentrations of $25 \mu \mathrm{g} / \mathrm{mL}$ [34]. In a study developed by Huang et al. [139], the authors reported that SeNPs 
of $81 \mathrm{~nm}$ inhibited completely methicillin-resistant and not methicillin-resistant Staphylococcus aureus. Interestingly, SeNPs of $81 \mathrm{~nm}(25 \mu \mathrm{g} / \mathrm{mL})$ showed greater antimicrobial activity compared to SeNPs of $124 \mathrm{~nm}(140 \mu \mathrm{g} / \mathrm{mL})$, even though the concentration of nanoparticles used was lower. However, when they are proved in their bactericidal activity, the behaviour is different. SeNPs of $43 \mathrm{~nm}$ and $81 \mathrm{~nm}$ at concentrations of $12.5 \mu \mathrm{g} / \mathrm{mL}$ and $0.78 \mu \mathrm{g} / \mathrm{mL}$, respectively, showed significant bactericidal activity toward S. aureus. In this case, the minimum concentration at which bactericidal effect of SeNPs was lower with the bigger particles.

Recent investigations have reported that antimicrobial activity is also dependent on the relationship between nanoparticle size and nanoparticle coatings, such as chitosan, bovine serum albumin (BSA) and glucose. In general, the highest antimicrobial activity is found in SeNPs associated with chitosan (SeNP-Chit), which showed a significantly larger size and diameter distribution $(>100 \mathrm{~nm})$ than SeNPs associated with bovine serum albumin $(<100 \mathrm{~nm})$. Although the SeNPs-Chit and those associated with glucose had a similar size, it was the SeNPs-Chit, which showed the highest antimicrobial activity [137].

Regarding the shape of the nanoparticles, it has been demonstrated that it has an influence on antimicrobial activity due to the interaction of the nanoparticle with the cell membrane. In this context, TEM analysis has shown that the most commonly reported form of SeNPs synthesized by bacteria are spherical, and in some cases, nano tubes or nanorods are observed along with spheres $[40,48,49,57,70,140]$. In contrast, SeNPs of chemical or physical origin has the shape of sheets, plates, tubes, rods, cubes, ribbons and triangles [128]. Nevertheless, spherical particles are more easily internalized within cells compared to large or elongated particles because the spherical form helps to be always in contact with the cell membrane [141]. Despite the relationship between form and interactions with the cell membrane, studies and antimicrobial activity of SeNPs are very scarce. On the other hand, there are different physicochemical and microbiological parameters that also affect the size and shape of SeNPs at the time of biogenic production.

\subsubsection{Physicochemical Parameters That Affect Shape and Size of SeNPs}

The uniform distribution of shape and size of SeNPs during bacterial synthesis is influenced by several parameters such as the effect of sodium selenite concentration, $\mathrm{pH}$ and temperature in the medium. In the case of sodium selenite concentration, Wadhwani et al. [49] reported that bacteria Acinetobacter sp. synthesizes SeNPs with the spherical shape at concentrations of 0.3 to $2.0 \mathrm{mM}$ of $\mathrm{Na}_{2} \mathrm{SeO}_{3}$. However, rod-like shapes were observed at higher concentrations ( 2.5 to $4.0 \mathrm{mM} \mathrm{Se}$ ), which at $3.0 \mathrm{mM}$ were shorter. In the same way, Moreno-Martin et al. [82] observed that the shape depends on the initial selenite concentration in culture media. Sodium selenite concentrations of $100 \mathrm{mg} / \mathrm{L}$ generate spherical SeNPs by fermentation of L. acidophilus and L. reuteri. However, L. bulgaricus with this same concentration of selenite synthesizes SeNPs in a star shape. This behaviour is also observed in methicillin-resistant Staphylococcus aureus; this bacterium synthesizes spherical SeNPs and nano rod-like structures, while E. coli, S. aureus and Pseudomona aeruginosa showed spherical SeNPs when they were cultured in the presence of $2 \mathrm{mM} \mathrm{Na}_{2} \mathrm{SeO}_{3}$ [40].

Like the shape, the size of SeNPs synthesized by bacteria is also influenced by selenite concentration. In a cell suspension of Acinetobacter sp. SW30 treated with different concentrations of $\mathrm{Na}_{2} \mathrm{SeO}_{3}(0.3,0.5,1.0$ and $1.5 \mathrm{mM})$ it is possible to obtain different diameter sizes of SeNPs (126, 96, 113 and $78 \mathrm{~nm}$, respectively). In this experiment, the authors reported the smallest synthesized particles at $1.5 \mathrm{mM}$ of $\mathrm{Na}_{2} \mathrm{SeO}_{3}$ [49]. Furthermore, Presentato et al. [142] reported that the size and aggregation of SeNPs are strongly influenced by the initial concentration of $\mathrm{Na}_{2} \mathrm{SeO}_{3}$ in media. The smallest SeNPs (71 and $53 \mathrm{~nm})$ obtained at the lowest concentration $\left(0.5 \mathrm{mM} \mathrm{Na}_{2} \mathrm{SeO}_{3}\right)$ evolve to form Se-nanorods, which are comparatively larger than those obtained at higher concentrations $(2 \mathrm{mM})$. Other parameters such as $\mathrm{pH}$ and temperature in the culture medium for the synthesis of SeNPs have also been studied. However, it has been observed that both parameters are related to the growth conditions of the bacteria and not to the formation of SeNPs, such as in chemical 
synthesis. For example, it has been reported that temperature for the synthesis of SeNPs of Acinetobacter sp. SW30 is at 30 and $37^{\circ} \mathrm{C}$, with the maximum observed synthesis at $37^{\circ} \mathrm{C}$, because the responsible proteins for the reduction of sodium selenite are active only at these temperatures [41,49]. Previous studies by Wang et al. [78] showed that when B. subtilis bacterium was subjected to a heat treatment (heating at $100{ }^{\circ} \mathrm{C}$ for $1 \mathrm{~h}$ ) to obtain SeNPs, the colour of the reaction solution did not change, which indicated that high temperatures caused the inactivation of bacteria enzymes and the synthesis of SeNPs was not carried out.

In relation to $\mathrm{pH}$, it has been found that at values of seven and nine, a maximum concentration of SeNPs is synthesized by Bacillus sp. EKT1 after $72 \mathrm{~h}$ of incubation using selenium dioxide as an inorganic selenium source in the medium [41]. Similarly, in Bacillus megaterium, the maximum synthesis of SeNPs is reached at $\mathrm{pH} 7$ and 8 , knowing that this microorganism grows under optimal conditions $\left(37^{\circ} \mathrm{C}, 0.25 \mathrm{mM} \mathrm{Na}_{2} \mathrm{SeO}_{3}, 30 \mathrm{~h}\right.$ incubation) at slightly alkaline $\mathrm{pH}$ [75]. On the other hand, when $\mathrm{pH}$ is between 6 and 9 during Acinobacter sp. growth, no significant effect was observed on the shape and size of synthesized SeNPs, and the concentration $(1.5$ and $3.0 \mathrm{nM})$ did not have a direct effect on these parameters [49].

\subsubsection{Microbiological Parameters That Affect SeNPs Size and Shape}

Several researchers have shown that SeNPs synthesized by bacteria evolve in size and shape depending on the incubation time. For example, Wang et al. [78] demonstrated that SeNPs synthesized by B. subtilis have a spherical shape which becomes elongated as the incubation time elapses. SeNPs synthesized in the first $24 \mathrm{~h}$ have a size of 50-150 $\mathrm{nm}$, while those synthesized after $48 \mathrm{~h}$ have a diameter close to $400 \mathrm{~nm}$. In another study, it was also observed that at short incubation times, the shape of SeNPs by Acinetobacter sp. is spherical in contrast to the elongated shape obtained with longer times (up to $48 \mathrm{~h}$ ). This effect is attributed to the Ostwald ripening process, which is caused by the high free energy derived from SeNPs [49].

On the other hand, the number and size of SeNPs synthesized by Stenotrophomonas maltophilia SeITE02 increase according to the incubation time when $0.5 \mathrm{mM}$ of sodium selenite concentration is in the medium, obtaining SeNPs of $150 \mathrm{~nm}$ in diameter after $24 \mathrm{~h}$ of incubation. This time is related to the end of the exponential phase, while in the late stationary phase (after $48 \mathrm{~h}$ ), this size can be between 100 to $300 \mathrm{~nm}$ [66]. Similarly, Lampis et al. [76] determined that SeNPs produced by Bacillus mycoides at $6 \mathrm{~h}$ of incubation have an average diameter of 50 to $100 \mathrm{~nm}$, and after $48 \mathrm{~h}$, their dimensions range between 50 and $400 \mathrm{~nm}$. This behaviour has also been observed in Pantoea agglomerans, Bacillus subtilis and Shewanella sp when SeNPs are produced [55,63,78].

Some authors indicate that the difference in SeNP size is attributed to the fact that the small nanoparticles produced in the first hours of incubation (at the beginning of the growth phase) behave as nucleation seeds for greater growth through a similar process to the Ostwald ripening mechanism [27,76]. However, other researchers have reported that smaller nanoparticle sizes are not always associated with short incubation times. For example, a study conducted by San Keskin et al. [36] reported SeNPs of similar sizes at different incubation times (150, 130 and $145 \mathrm{~nm}$ at 24,48 and $72 \mathrm{~h}$, respectively) synthesized by Lysinibacillus sp. NOSK, this study was realized using a concentration of $1 \mathrm{mM}$ of $\mathrm{Na}_{2} \mathrm{SeO}_{3}$. In this sense, several investigations attribute the differences in size and shape to each bacteria's own metabolism. This could be a consequence of the different mechanisms that bacteria use for the synthesis of SeNPs. This can be clearly observed in a study carried out by Moreno-Martin et al. [136], who synthesized SeNPs of three lactobacilli (L. acidophilus, L. bulgaricus and L. reuteri), indicating, through histogram distribution, that the species determines both SeNPs size and shape.

In this review, a data collection of SeNPs synthesized by Gram-positive and Gramnegative bacteria analyzed by Transmission Electron Microscopy (TEM) and Scanning Electron Microscope (SEM) are listed in Table 1. These data demonstrate that the sizes of the obtained SeNPs depend on the bacteria metabolism. Thus, the largest particle sizes 
have been found in Pseudomonas with sizes from 50 to $500 \mathrm{~nm}$ [58-60], in Burkholderia from 170 to $200 \mathrm{~nm}$ [43], and Shewanella sp. < $103 \mathrm{~nm}[63,85]$. Stenotrophomonas maltophilia produces SeNPs of different sizes, ranging from 100 to $400 \mathrm{~nm}[65,111]$. Other bacteria such as Azospirillum brasilense [51], Providencia vermicola [57], E. coli K-12 [53] and Zooglea ramigera [70] synthesize SeNPs with sizes from 50 to $400 \mathrm{~nm}$. While within the Grampositive bacteria group, Lactobacillus sp. synthesize the smallest particle sizes $(2-80 \mathrm{~nm})$ compared to Bacillus sp. with sizes from 20 to $400 \mathrm{~nm}$ and Streptococcus with sizes between 50 and $100 \mathrm{~nm}$.

\section{Antimicrobial Action Mechanisms}

Antimicrobial activity of SeNPs, alone or in combination with standard antibiotics, has been tested against a wide range of microorganisms, including Gram-negative, Grampositive bacteria, and fungi $[34,40,57,65,143]$. However, studies are scarce about the mechanisms of antimicrobial action of these nanoparticles. In general, it has been proposed that some nanoparticles can follow three mechanisms: (i) cell wall and membrane damage, (ii) intracellular penetration, and (iii) oxidative stress [32,33,136,144].

\subsection{Cell Wall and Membrane Damage}

Cell wall and membrane components could be involved in different adhesion pathways for nanoparticles. One of the functions of the cell wall and membrane is to protect the microorganism against environmental threats while maintaining its homeostasis, allowing nutrients transport within the cell. These characteristics are part of the bacterial classification, which is based on differences in cell wall structures. Thus, the cell wall of Gram-negative bacteria has a thin layer of peptidoglycan with an additional outer membrane consisting of lipopolysaccharide. On the other hand, the cell wall of Gram-positive bacteria is typically thicker and is mainly composed of peptidoglycans [131]. These structures are modified by the physical interaction between nanoparticles and the cell wall but are more damaging for Gram-negative bacteria; although it is found as an associated lipopolysaccharides layer in them, they lack the thick peptidoglycan layer found in Gram-positive bacteria [145].

Cell wall confers a negative charge on both Gram-positive and negative bacteria at neutral $\mathrm{pH}$ [130-133]. However, Gram-negative bacteria represent the set of microorganisms with the highest negative charge. In addition, Gram-negative bacteria have an outer membrane composed of phospholipids with partially phosphorylated lipopolysaccharides that increase the negative charge of their cell envelope [32,146,147]. This negative charge is supposed to influence the interactions between the bacterium cell wall and the NPs or ions released from them. When SeNPs are interacted with bioorganic compounds positively charged, such as proteins or amino acids, they are attracted to the cell negative wall binding by electrostatic interactions. These nanoparticles lead to the formation of a strong bond with membranes, causing cell wall rupture and permeability $[32,129,134,136,137]$. Thus, the interaction between SeNPs and microorganisms begins with their adhesion to the microbial wall and cell membrane. This binding is based on the electrostatic attraction between the negatively charged microbial cell membrane and the positive or less negatively charged SeNPs [33]. After the attraction and interaction of SeNPs with the microorganism, structural and morphological changes are caused by the SeNPs, leading to the interruption of both membrane permeability and respiratory functions. This effect takes place through membrane depolarization, disruption of cell integrity, and finally, cell death $[31,128]$. As a result of increased membrane permeability and cell wall disruption, cell contents, including proteins, enzymes, DNA, ions, metabolites and energy reserves, seep into the environment $[33-35,131]$. Therefore, the disintegration of the cell wall by the adhesion of nanoparticles is the main mechanism of antimicrobial action. To demonstrate this mechanism, Huang et al. [31] evaluated the effect of SeNPs on the cell membrane using propidium iodide and cyanine diSC $3-5$ fluorescent dyes. For both dyes, the increase of the fluorescence indicated membrane damage. In this study, E. coli and S. aureus MDR 
cells were treated with SeNPs coated with quercetin (Qui), acetylcholine (Ach) and the mixture of both. The results showed a significant increase $(p<0.01)$ in the fluorescence of dyes when the bacteria were incubated with Qu-Ach-SeNPs $(25 \mu \mathrm{g} / \mathrm{mL})$ and Ach-SeNPs $(25 \mu \mathrm{g} / \mathrm{mL})$, indicating an increase in the total permeability of the membrane.

SEM and TEM analyses showed that when bacteria are treated with SeNPs, they have a cellular contraction and take an irregular shape compared to a control group of bacteria $[31,35,128,139]$. For example, after incubation of E. coli and S. aureus with coated SeNPs, cell lysis and intracellular leakage were observed in E. coli, while in S. aureus, there were sunken cell walls and cytoplasmic release, including cell wall disorganization [31]. When B. subtilis is in contact with SeNP-soluble starch, the cells shrink and fragment in such a way that the cell shape becomes irregular, and the size shows significant differences [128]. In another study, Zhang et al. [33] evaluated the effects of bio-SeNPs on the cell wall of Gram-positive bacteria (S. aureus, B. cereus and B. subtilis) and Gram-negative (P. aeruginosa, E. coli and V. parahemolyticus). Bacteria treated with bio-SeNPs were damaged in different levels, and Gram-negative bacteria and B. subtilis showed pits and holes on the surface. While in S. aureus, some membranes were found to be wrinkled, flattened and surrounded by cytoplasm, which indicated the leakage of intracellular content. Additionally, these authors demonstrated that bio-SeNPs accelerate proteins and polysaccharides leakage from the bacterial cytoplasm.

In addition, the mechanism by which SeNPs damage bacteria cytoplasmic membrane is by producing a rapid depolarization of the membrane [145]. Thus, Huang et al. [139] investigated SeNPs effect on S. aureus polarity cell membranes. As a result, they reported that bacteria treated with SeNPs led to mild membrane depolarization in a dose-dependent form. At concentrations of 6.25 and $12.5 \mu \mathrm{g} / \mathrm{mL}$ of SeNPs $(43 \mathrm{~nm}), 15$ and $25 \%$ of depolarized cells were obtained, respectively. But with higher SeNPs $(81 \mathrm{~nm})$ in the same concentrations, 20 and $30 \%$ of depolarized cells were obtained. Finally, cells treated with particles larger than $124 \mathrm{~nm}$ retained their spherical shape and smooth cell wall.

On the other hand, Huang et al. [139] proposed that SeNPs have a related mechanism to metabolic interference through the alteration of intracellular concentrations of adenosine triphosphate (ATP). ATP is a compound that provides energy used by all living organisms. It plays a vital role in both respiration and metabolism, as it is the most important energy supplier for many enzymatic reactions. Therefore, these authors studied the effects of different concentrations and sizes of SeNPs on the ATP level of S. aureus. They found that S. aureus cultures treated with SeNPs, showed a significant decrease in ATP, regarding the greatest induced depletion using $81 \mathrm{~nm}$ particles. This rapid depletion of cellular ATP is a characteristic of an energy uncoupling effect.

\subsection{Intracellular Penetration and Damage}

Metabolic functions of the cell are affected since NPs penetrate through the membrane, especially when it presents a certain level of damage interacting with DNA and proteins [148]. This action represents one of the proposed mechanisms for the antimicrobial activity of NPs, which is based on the release of ions [149]. In this sense, several researchers have reported that $\mathrm{Se}^{0}$ is soluble in trace concentrations in aqueous environments. Therefore, the amount of Se ions released from SeNPs is likely to be very small. In other words, the antimicrobial effects of Se ions may be too weak, representing a not significant mechanism of SeNPs [136,139]. In one study, Galić et al. [136] observed that the antibacterial effect of SeNPs with different coatings against $S$. aureus was only due to the particles, and the release of Se ions is not implicated in the antimicrobial action. This was because the solubilized fractions of SeNPs showed very low values, and when the selenite antimicrobial effect was tested, it did not show any effect at high concentrations $(\mathrm{MBC}>100 \mathrm{mg} \mathrm{Se} / \mathrm{L})$. Although the studies are very recent, they mark a trend in research proposals to encompass the entire set of antimicrobial mechanisms associated with the penetration of compounds through the cell membrane of bacteria and their subsequent interaction within their metabolism. 


\subsection{Oxidative Stress}

Reactive oxygen species (ROS) are oxygen-containing molecules that have a strong redox potential. Under normal conditions, the production of ROS and the antioxidant capacity of the cell are balanced. However, if there is an imbalance between the antioxidant mechanism and the excessive production of ROS, the redox balance of the cell favours oxidation, and this causes oxidative stress. Furthermore, oxidative stress is a cellular process involved in many aspects of cell signalling, although when it occurs excessively, it causes irreversible damage to cell metabolism, affecting viability $[32,37,150]$.

The literature reports that after the addition of SeNPs, these are absorbed on the surface of bacteria and trigger cellular oxidative stress $[33,37,144]$. To overcome this stress, cells exhibit protective responses that include enzymatic or non-enzymatic defence mechanisms [148]. When oxidative stress overcomes defence mechanisms, the cell wall and biomolecules such as proteins, lipids and DNA are subjected to damage caused by ROS and free radicals such as hypochlorous acid $(\mathrm{HOCl})$, hydrogen peroxide $\left(\mathrm{H}_{2} \mathrm{O}_{2}\right)$, hydroxyl radical $(\mathrm{OH})$, superoxide anion $\left(\mathrm{O}_{2}^{-}\right)$and singlet oxygen $\left({ }^{1} \mathrm{O}_{2}\right)[37,144]$. In this sense, Huang et al. [33] proved that oxidative damage is the cause of bacterial death of species such as E. coli and S. aureus when treated with SeNPs. This study showed that when total ROS concentrations were measured in Quercetin and Acetylcholine SeNPs (Qu-Ach @ SeNPs) treated bacteria, ROS production significantly increased in both cultures. On the other hand, in SeNPs-quercetin and SeNPs-acetylcholine, a significant increase in ROS production was not observed in treated $E$. coli. This indicates that the antibacterial activity of Qu-Ach @ SeNPs is related to the generation of ROS.

In another study, Huang et al. [139] reported that SeNPs also promoted ROS production in S. aureus cells. These compounds were measured by the fluorescence produced in the presence of $43 \mathrm{~nm}$ and $81 \mathrm{~nm}$ SeNPs in the medium. The results showed an increase of up to $8 \%$ and $10 \%$ of the concentration of ROS. In comparison, the formation of ROS is not higher than $2 \%$ when SeNPs are not present in the medium. Similarly, Zhang et al. [33] showed that ROS generation is responsible for antibacterial activity when Bio-SeNPs were tested against Gram-positive and Gram-negative bacteria. ROS generation was performed using a fluorescence microplate system, in which the emission intensity was not greater than 10,000 bacteria without contact with SeNPs. After the addition of SeNPs, the intensity increased for all tested microorganisms: 50,000 for P. aeruginosa, 23,000 for E. coli, 20,000 for V. parahemolyticus and S. aureus, and finally 150,000 for B. subtilis. From the previous results, it was indicated that the increase in ROS induced by bio-SeNPs would be one of the most important antibacterial mechanisms. Research has indicated that ROS production has a significant effect on cell death and that it could be enhanced by the presence of Se contained in nanoparticles. This would prove the antimicrobial capacity of SeNPs; however, a greater number of reports are required, in which the biochemical mechanisms of action must be identified.

\section{Conclusions}

The opportunities that SeNP offer in fields such as medicine and food technology are highlighted in this review. Both food processing and current medicine have a common denominator, which is innovation. Technological advances have allowed more studies, such as those shown in this work, to have applications in conjunction with transformation processes. In this sense, obtaining biogenic nanoparticles derived from the biotransformation of inorganic species of selenium into selenium nanoparticles by bacteria is established. However, in order to determine the optimum parameters to develop efficient biotransformation of selenium to obtain SeNPs with potential antimicrobial activity, it is necessary to know the selenium biotransformation pathway of bacteria. In this review, different mechanisms of the formation of biogenic SeNPs of microbial origin were considered together with different factors that affect antimicrobial activity. The relation between shape, size and concentration of selenium nanoparticles and other physicochemical characteristics are considered to elevate an effective action of this kind of particles. In addition, the microbial growth 
phase and initial concentration of selenium source in the medium have to be defined to optimize the synthesis process of SeNPs. Furthermore, it was discovered that particles synthesized by certain bacteria could have a direct effect on their development when these isolated nanoparticles were tested. That is why this represents an opportunity in the field of research to determine the mechanisms of antimicrobial action of functional particles.

However, there are challenges that must be met and gaps in research that need to be filled, especially in antimicrobial activity mechanisms and the biochemical routes of inorganic to organic biotransformation of selenium by bacteria, which are fields that need to be studied more deeply. Furthermore, the application in food and medicine have to be studied in-depth to give way to benefits that these type of particles offer to human health and to food science and technology.

Author Contributions: Conceptualization, M.C.E.-R., L.G.G.-O., A.C.-O. and E.P.-E.; methodology, G.M.R.-S.; investigation, M.C.E.-R. and L.G.G.-O.; resources, E.R.-M. and A.Q.-L.; writing-original draft preparation, M.C.E.-R., J.J.-O. and E.C.-L.; writing-review and editing, J.J.-O. and J.A.-M.; supervision, L.G.G.-O. All authors have read and agreed to the published version of the manuscript.

Funding: This work was supported by the Consejo Nacional de Ciencia y Tecnología (CONACYT), Mexico, under Grant number CB-2014-241333.

Institutional Review Board Statement: Not applicable.

Informed Consent Statement: Not applicable.

Data Availability Statement: Not applicable.

Acknowledgments: The authors appreciate the support of CONACYT for the Ph.D. scholarship number 473399 granted to Meyli C Escobar Ramírez. We thank QFB Juan Escobar Ramírez for their collaboration in the figure design of this work.

Conflicts of Interest: The authors declare no conflict of interest.

\section{References}

1. Greeshma, B.C.; Mahesh, M. Biosynthesis of selenium nanoparticles from Bacillus species and its applications. J. Appl. Nat. Sci. 2019, 11, 810-815. [CrossRef]

2. Strambeanu, N.; Demetrovici, L.; Dragos, D.; Lungu, M. Nanoparticles: Definition, Classification and General Physical Properties. In Nanoparticles' Promises and Risks; Lungu, M., Neculae, A., Bunoiu, M.B.C., Eds.; Springer: Cham, Switzerland, 2015; pp. 3-8. ISBN 9783319117287.

3. El-Batal, A.I.; Mosallam, F.M.; Ghorab, M.M.; Hanora, A.; Gobara, M.; Baraka, A.; Elsayed, M.A.; Pal, K.; Fathy, R.M.; Abd Elkodous, M.; et al. Factorial design-optimized and gamma irradiation-assisted fabrication of selenium nanoparticles by chitosan and Pleurotus ostreatus fermented fenugreek for a vigorous in vitro effect against carcinoma cells. Int. J. Biol. Macromol. 2020, 156, 1584-1599. [CrossRef] [PubMed]

4. Shi, X.D.; Tian, Y.Q.; Wu, J.L.; Wang, S.Y. Synthesis, characterization, and biological activity of selenium nanoparticles conjugated with polysaccharides. Crit. Rev. Food Sci. Nutr. 2020, 61, 2225-2236. [CrossRef] [PubMed]

5. Ojeda, J.J.; Merroun, M.L.; Tugarova, A.V.; Lampis, S.; Kamnev, A.A.; Gardiner, P.H.E. Developments in the study and applications of bacterial transformations of selenium species. Crit. Rev. Biotechnol. 2020, 40, 1250-1264. [CrossRef]

6. Zambonino, M.C.; Quizhpe, E.M.; Jaramillo, F.E.; Rahman, A.; Santiago-Vispo, N.; Jeffryes, C.; Dahoumane, S.A. Green synthesis of selenium and tellurium nanoparticles: Current trends, biological properties and biomedical applications. Int. J. Mol. Sci. 2021, 22, 989. [CrossRef]

7. Ranjitha, V.R.; Rai, V.R. Selenium nanostructure: Progress towards green synthesis and functionalization for biomedicine. J. Pharm. Investig. 2021, 51, 117-135. [CrossRef]

8. Kessi, J.; Ramuz, M.; Wehrli, E.; Spycher, M.; Bachofen, R. Reduction of selenite and detoxification of elemental selenium by the phototrophic bacterium Rhodospirillum rubrum. Appl. Environ. Microbiol. 1999, 65, 4734-4740. [CrossRef]

9. Palomo-Siguero, M.; Gutiérrez, A.M.; Pérez-Conde, C.; Madrid, Y. Effect of selenite and selenium nanoparticles on lactic bacteria: A multi-analytical study. Microchem. J. 2016, 126, 488-495. [CrossRef]

10. Wang, Y.; Shu, X.; Zhou, Q.; Fan, T.; Wang, T.; Chen, X.; Li, M.; Ma, Y.; Ni, J.; Hou, J.; et al. Selenite reduction and the biogenesis of selenium nanoparticles by Alcaligenes faecalis se03 isolated from the gut of Monochamus alternatus (Coleoptera: Cerambycidae). Int. J. Mol. Sci. 2018, 19, 2799. [CrossRef] [PubMed]

11. Zhang, J.; Wang, X.; Xu, T. Elemental selenium at nano size (Nano-Se) as a potential chemopreventive agent with reduced risk of selenium toxicity: Comparison with se-methylselenocysteine in mice. Toxicol. Sci. 2008, 101, 22-31. [CrossRef] [PubMed] 
12. Maseko, T.; Callahan, D.L.; Dunshea, F.R.; Doronila, A.; Kolev, S.D.; Ng, K. Chemical characterisation and speciation of organic selenium in cultivated selenium-enriched Agaricus bisporus. Food Chem. 2013, 141, 3681-3687. [CrossRef]

13. Mangiapane, E.; Pessione, A.; Pessione, E. Selenium and selenoproteins: An overview on different biological systems. Curr. Protein Pept. Sci. 2014, 15, 598-607. [CrossRef] [PubMed]

14. Kim, H.Y.; Gladyshev, V.N. Different catalytic mechanisms in mammalian selenocysteine- and cysteine-containing methionine-Rsulfoxide reductases. PLoS Biol. 2005, 3, 2080-2089. [CrossRef]

15. Scortecci, J.F.; Serrão, V.H.B.; Fernandes, A.F.; Basso, L.G.M.; Gutierrez, R.F.; Araujo, A.P.U.; Neto, M.O.; Thiemann, O.H. Initial steps in selenocysteine biosynthesis: The interaction between selenocysteine lyase and selenophosphate synthetase. Int. J. Biol. Macromol. 2020, 156, 18-26. [CrossRef]

16. Stock, T.; Rother, M. Selenoproteins in Archaea and Gram-positive bacteria. Biochim. Biophys. Acta Gen. Subj. 2009, 1790, 1520-1532. [CrossRef] [PubMed]

17. Sumner, S.E.; Markley, R.L.; Kirimanjeswara, G.S. Role of selenoproteins in bacterial pathogenesis. Biol. Trace Elem. Res. 2019, 192, 69-82. [CrossRef]

18. Lobanov, A.V.; Hatfield, D.L.; Gladyshev, V.N. Eukaryotic selenoproteins and selenoproteomes. Biochim. Biophys. Acta Gen. Subj. 2009, 1790, 1424-1428. [CrossRef]

19. Avery, J.C.; Hoffmann, P.R. Selenium, selenoproteins, and immunity. Nutrients 2018, 10, 1203. [CrossRef] [PubMed]

20. Santos, L.; Neves, C.; Melo, M.; Soares, P. Selenium and selenoproteins in immune mediated thyroid disorders. Diagnostics 2018, 8, 70. [CrossRef]

21. Winther, K.H.; Rayman, M.P.; Bonnema, S.J.; Hegedüs, L. Selenium in thyroid disorders-Essential knowledge for clinicians. Nat. Rev. Endocrinol. 2020, 16, 165-176. [CrossRef]

22. Roman, M.; Jitaru, P.; Barbante, C. Selenium biochemistry and its role for human health. Metallomics 2014, 6, 25-54. [CrossRef]

23. Qazi, I.H.; Angel, C.; Yang, H.; Zoidis, E.; Pan, B.; Wu, Z.; Ming, Z.; Zeng, C.J.; Meng, Q.; Han, H.; et al. Role of selenium and selenoproteins in male reproductive function: A review of past and present evidences. Antioxidants 2019, 8, 268. [CrossRef]

24. Zhang, H.; Zhou, H.; Bai, J.; Li, Y.; Yang, J.; Ma, Q.; Qu, Y. Biosynthesis of selenium nanoparticles mediated by fungus Mariannaea sp. HJ and their characterization. Colloids Surf. A Physicochem. Eng. Asp. 2019, 571, 9-16. [CrossRef]

25. Fernández-Llamosas, H.; Castro, L.; Blázquez, M.L.; Díaz, E.; Carmona, M. Biosynthesis of selenium nanoparticles by Azoarcus sp. CIB. Microb. Cell Fact. 2016, 15, 109. [CrossRef]

26. Staicu, L.C.; van Hullebusch, E.D.; Lens, P.N.L. Production, recovery and reuse of biogenic elemental selenium. Environ. Chem. Lett. 2015, 13, 89-96. [CrossRef]

27. Tugarova, A.V.; Mamchenkova, P.V.; Khanadeev, V.A.; Kamnev, A.A. Selenite reduction by the rhizobacterium Azospirillum brasilense, synthesis of extracellular selenium nanoparticles and their characterisation. New Biotechnol. 2020, 58, 17-24. [CrossRef] [PubMed]

28. Turner, R.J.; Weiner, J.H.; Taylor, D.E. Selenium metabolism in Escherichia coli. BioMetals 1998, 11, 223-227. [CrossRef] [PubMed]

29. Debieux, C.M.; Dridge, E.J.; Mueller, C.M.; Splatt, P.; Paszkiewicz, K.; Knight, I.; Florance, H.; Love, J.; Titball, R.W.; Lewis, R.J.; et al. A bacterial process for selenium nanosphere assembly. Proc. Natl. Acad. Sci. USA 2011, 108, 13480-13485. [CrossRef] [PubMed]

30. Rehan, M.; Alsohim, A.S.; El-Fadly, G.; Tisa, L.S. Detoxification and reduction of selenite to elemental red selenium by Frankia. Antonie Van Leeuwenhoek 2019, 112, 127-139. [CrossRef]

31. Huang, X.; Chen, X.; Chen, Q.; Yu, Q.; Sun, D.; Liu, J. Investigation of functional selenium nanoparticles as potent antimicrobial agents against superbugs. Acta Biomater. 2016, 30, 397-407. [CrossRef]

32. Sánchez-López, E.; Gomes, D.; Esteruelas, G.; Bonilla, L.; Lopez-Machado, A.L.; Galindo, R.; Cano, A.; Espina, M.; Ettcheto, M.; Camins, A.; et al. Metal-based nanoparticles as antimicrobial agents: An overview. Nanomaterials 2020, 10, 292. [CrossRef]

33. Zhang, H.; Li, Z.; Dai, C.; Wang, P.; Fan, S.; Yu, B.; Qu, Y. Antibacterial properties and mechanism of selenium nanoparticles synthesized by Providencia sp. DCX. Environ. Res. 2021, 194, 110630. [CrossRef]

34. Khiralla, G.M.; El-Deeb, B.A. Antimicrobial and antibiofilm effects of selenium nanoparticles on some foodborne pathogens. LWT Food Sci. Technol. 2015, 63, 1001-1007. [CrossRef]

35. Nguyen, T.H.D.; Vardhanabhuti, B.; Lin, M.; Mustapha, A. Antibacterial properties of selenium nanoparticles and their toxicity to Caco-2 cells. Food Control 2017, 77, 17-24. [CrossRef]

36. San Keskin, N.O.S.; Vural, O.A.; Abaci, S. Biosynthesis of noble selenium nanoparticles from Lysinibacillus sp. NOSK for antimicrobial, antibiofilm activity, and biocompatibility. Geomicrobiol. J. 2020, 37, 919-928. [CrossRef]

37. Dayem, A.A.; Hossain, M.K.; Lee, S.B.; Kim, K.; Saha, S.K.; Yang, G.M.; Choi, H.Y.; Cho, S.G. The role of reactive oxygen species (ROS) in the biological activities of metallic nanoparticles. Int. J. Mol. Sci. 2017, 18, 120. [CrossRef] [PubMed]

38. Zonaro, E.; Lampis, S.; Turner, R.J.; Qazi, S.J.S.; Vallini, G. Biogenic selenium and tellurium nanoparticles synthesized by environmental microbial isolates efficaciously inhibit bacterial planktonic cultures and biofilms. Front. Microbiol. 2015, 6, 584. [CrossRef]

39. Alam, H.; Khatoon, N.; Khan, M.A.; Husain, S.A.; Saravanan, M.; Sardar, M. Synthesis of selenium nanoparticles using probiotic bacteria Lactobacillus acidophilus and their enhanced antimicrobial activity against resistant bacteria. J. Clust. Sci. 2020, 31, 1003-1011. [CrossRef] 
40. Medina-Cruz, D.; Mi, G.; Webster, T.J. Synthesis and characterization of biogenic selenium nanoparticles with antimicrobial properties made by Staphylococcus aureus, methicillin-resistant Staphylococcus aureus (MRSA), Escherichia coli, and Pseudomonas aeruginosa. J. Biomed. Mater. Res. Part A 2018, 106, 1400-1412. [CrossRef] [PubMed]

41. Akçay, F.A.; Avc1, A. Effects of process conditions and yeast extract on the synthesis of selenium nanoparticles by a novel indigenous isolate Bacillus sp. EKT1 and characterization of nanoparticles. Arch. Microbiol. 2020, 202, 2233-2243. [CrossRef] [PubMed]

42. Piacenza, E.; Presentato, A.; Zonaro, E.; Lemire, J.A.; Demeter, M.; Vallini, G.; Turner, R.J.; Lampis, S. Antimicrobial activity of biogenically produced spherical Se-nanomaterials embedded in organic material against Pseudomonas aeruginosa and Staphylococcus aureus strains on hydroxyapatite-coated surfaces. Microb. Biotechnol. 2017, 10, 804-818. [CrossRef]

43. Khoei, N.S.; Lampis, S.; Zonaro, E.; Yrjälä, K.; Bernardi, P.; Vallini, G. Insights into selenite reduction and biogenesis of elemental selenium nanoparticles by two environmental isolates of Burkholderia fungorum. New Biotechnol. 2017, 34, 1-11. [CrossRef] [PubMed]

44. Xu, C.; Qiao, L.; Ma, L.; Yan, S.; Guo, Y.; Dou, X.; Zhang, B.; Roman, A. Biosynthesis of polysaccharides-capped selenium nanoparticles using Lactococcus lactis NZ9000 and their antioxidant and anti-inflammatory activities. Front. Microbiol. 2019, 10, 1632. [CrossRef] [PubMed]

45. Gerrard, T.L.; Telford, J.N.; Williams, H.H. Detection of selenium deposits in Escherichia coli by electron microscopy. J. Bacteriol. 1974, 119, 1057-1060. [CrossRef]

46. Bharathi, S.; Kumaran, S.; Suresh, G.; Ramesh, M.; Thangamani, V.; Pugazhvendan, S.R.; Sathiyamurthy, K. Extracellular synthesis of nanoselenium from fresh water bacteria Bacillus sp., and its validation of antibacterial and cytotoxic potential. Biocatal. Agric. Biotechnol. 2020, 27, 101655. [CrossRef]

47. Fischer, S.; Krause, T.; Lederer, F.; Merroun, M.L.; Shevchenko, A.; Hübner, R.; Firkala, T.; Stumpf, T.; Jordan, N.; Jain, R. Bacillus safensis JG-B5T affects the fate of selenium by extracellular production of colloidally less stable selenium nanoparticles. J. Hazard. Mater. 2020, 384, 121146. [CrossRef]

48. Ruiz-Fresneda, M.A.; Eswayah, A.S.; Romero-González, M.; Gardiner, P.H.E.; Solari, P.L.; Merroun, M.L. Chemical and structural characterization of Se (IV) biotransformations by Stenotrophomonas bentonitica into $\mathrm{Se}^{0}$ nanostructures and volatiles Se species. Environ. Sci. Nano 2020, 7, 2140-2155. [CrossRef]

49. Wadhwani, S.A.; Gorain, M.; Banerjee, P.; Shedbalkar, U.U.; Singh, R.; Kundu, G.C.; Chopade, B.A. Green synthesis of selenium nanoparticles using Acinetobacter sp. SW30: Optimization, characterization and its anticancer activity in breast cancer cells. Int. J. Nanomed. 2017, 12, 6841-6855. [CrossRef]

50. Bajaj, M.; Schmidt, S.; Winter, J. Formation of Se (0) Nanoparticles by Duganella sp. and Agrobacterium sp. isolated from Se-laden soil of North-East Punjab, India. Microb. Cell Fact. 2012, 11, 1-14. [CrossRef]

51. Tugarova, A.V.; Vetchinkina, E.P.; Loshchinina, E.A.; Burov, A.M.; Nikitina, V.E.; Kamnev, A.A. Reduction of selenite by Azospirillum brasilense with the formation of selenium nanoparticles. Microb. Ecol. 2014, 68, 495-503. [CrossRef]

52. Zheng, S.; Su, J.; Wang, L.; Yao, R.; Wang, D.; Deng, Y.; Wang, R.; Wang, G.; Rensing, C. Selenite reduction by the obligate aerobic bacterium Comamonas testosteroni S44 isolated from a metal-contaminated soil. BMC Microbiol. 2014, 14, 204. [CrossRef] [PubMed]

53. Dobias, J.; Suvorova, E.I.; Bernier-Latmani, R. Role of proteins in controlling selenium nanoparticle size. Nanotechnology 2011, 22, 195605. [CrossRef]

54. Kazempour, Z.B.; Yazdi, M.H.; Rafii, F.; Shahverdi, A.R. Sub-inhibitory concentration of biogenic selenium nanoparticles lacks post antifungal effect for Aspergillus niger and Candida albicans and stimulates the growth of Aspergillus niger. Iran. J. Microbiol. 2013, 5, 81-85. [PubMed]

55. Torres, S.K.; Campos, V.L.; León, C.G.; Rodríguez-Llamazares, S.M.; Rojas, S.M.; González, M.; Smith, C.; Mondaca, M.A. Biosynthesis of selenium nanoparticles by Pantoea agglomerans and their antioxidant activity. J. Nanopart. Res. 2012, $14,1236$. [CrossRef]

56. Wang, Y.; Shu, X.; Hou, J.; Lu, W.; Zhao, W.; Huang, S.; Wu, L. Selenium nanoparticle synthesized by Proteus mirabilis YC801: An efficacious pathway for selenite biotransformation and detoxification. Int. J. Mol. Sci. 2018, 19, 3809. [CrossRef] [PubMed]

57. El-Deeb, B.; Al-Talhi, A.; Mostafa, N.; Abou-assy, R. Biological synthesis and structural characterization of selenium nanoparticles and assessment of their antimicrobial properties. Am. Sci. Res. J. Eng. Technol. Sci. 2018, 45, 135-170.

58. Dwivedi, S.; AlKhedhairy, A.A.; Ahamed, M.; Musarrat, J. Biomimetic synthesis of selenium nanospheres by bacterial strain JS-11 and its role as a biosensor for nanotoxicity assessment: A Novel Se-Bioassay. PLoS ONE 2013, 8, e57404. [CrossRef]

59. Zhang, W.; Chen, Z.; Liu, H.; Zhang, L.; Gao, P.; Li, D. Biosynthesis and structural characteristics of selenium nanoparticles by Pseudomonas alcaliphila. Colloids Surf. B Biointerfaces 2011, 88, 196-201. [CrossRef]

60. Avendaño, R.; Chaves, N.; Fuentes, P.; Sánchez, E.; Jiménez, J.I.; Chavarría, M. Production of selenium nanoparticles in Pseudomonas putida KT2440. Sci. Rep. 2016, 6, 37155. [CrossRef]

61. Li, B.; Liu, N.; Li, Y.; Jing, W.; Fan, J.; Li, D.; Zhang, L.; Zhang, X.; Zhang, Z.; Wang, L. Reduction of selenite to red elemental selenium by Rhodopseudomonas palustris strain N. PLoS ONE 2014, 9, e95955. [CrossRef]

62. Oremland, R.S.; Herbel, M.J.; Blum, J.S.; Langley, S.; Beveridge, T.J.; Ajayan, P.M.; Sutto, T.; Ellis, A.V.; Curran, S. Structural and spectral features of selenium nanospheres produced by Se-respiring bacteria. Appl. Environ. Microbiol. 2004, 70, 52-60. [CrossRef]

63. Tam, K.; Ho, C.T.; Lee, J.H.; Lai, M.; Chang, C.H.; Rheem, Y.; Chen, W.; Hur, H.G.; Myung, N.V. Growth mechanism of amorphous selenium nanoparticles synthesized by Shewanella sp. HN-41. Biosci. Biotechnol. Biochem. 2010, 74, 696-700. [CrossRef] 
64. Dungan, R.S.; Yates, S.R.; Frankenberger, W.T. Transformations of selenate and selenite by Stenotrophomonas maltophilia isolated from a seleniferous agricultural drainage pond sediment. Environ. Microbiol. 2003, 5, 287-295. [CrossRef] [PubMed]

65. Cremonini, E.; Zonaro, E.; Donini, M.; Lampis, S.; Boaretti, M.; Dusi, S.; Melotti, P.; Lleo, M.M.; Vallini, G. Biogenic selenium nanoparticles: Characterization, antimicrobial activity and effects on human dendritic cells and fibroblasts. Microb. Biotechnol. 2016, 9, 758-771. [CrossRef]

66. Lampis, S.; Zonaro, E.; Bertolini, C.; Cecconi, D.; Monti, F.; Micaroni, M.; Turner, R.J.; Butler, C.S.; Vallini, G. Selenite biotransformation and detoxification by Stenotrophomonas maltophilia SeITE02: Novel clues on the route to bacterial biogenesis of selenium nanoparticles. J. Hazard. Mater. 2017, 324, 3-14. [CrossRef]

67. Ramya, S.; Shanmugasundaram, T.; Balagurunathan, R. Biomedical potential of actinobacterially synthesized selenium nanoparticles with special reference to anti-biofilm, anti-oxidant, wound healing, cytotoxic and anti-viral activities. J. Trace Elem. Med. Biol. 2015, 32, 30-39. [CrossRef] [PubMed]

68. Hnain, A.; Brooks, J.; Lefebvre, D.D. The synthesis of elemental selenium particles by Synechococcus leopoliensis. Appl. Microbiol. Biotechnol. 2013, 97, 10511-10519. [CrossRef]

69. Fernández-Llamosas, H.; Castro, L.; Blázquez, M.L.; Díaz, E.; Carmona, M. Speeding up bioproduction of selenium nanoparticles by using Vibrio natriegens as microbial factory. Sci. Rep. 2017, 7, 16046. [CrossRef] [PubMed]

70. Srivastava, N.; Mukhopadhyay, M. Biosynthesis and structural characterization of selenium nanoparticles mediated by Zooglea ramigera. Powder Technol. 2013, 244, 26-29. [CrossRef]

71. Dhanjal, S.; Cameotra, S.S. Aerobic biogenesis of selenium nanospheres by Bacillus cereus isolated from coalmine soil. Microb. Cell Fact. 2010, 9, 52. [CrossRef]

72. Pouri, S.; Motamedi, H.; Honary, S.; Kazeminezhad, I. Biological synthesis of selenium nanoparticles and evaluation of their bioavailability. Braz. Arch. Biol. Technol. 2017, 60, e170452. [CrossRef]

73. Ali, E.N.; El-Sonbaty, S.M.; Salem, F.M. Evaluation of selenium nanoparticles as a potential chemopreventive agent against lung carcinoma. Int. J. Pharm. Biol. Sci. 2013, 2, 38-46.

74. Sonkusre, P.; Nanduri, R.; Gupta, P.; Cameotra, S.S. Improved extraction of intracellular biogenic selenium nanoparticles and their specificity for cancer chemoprevention. J. Nanomed. Nanotechnol. 2014, 5, 1000194. [CrossRef]

75. Mishra, R.R.; Prajapati, S.; Das, J.; Dangar, T.K.; Das, N.; Thatoi, H. Reduction of selenite to red elemental selenium by moderately halotolerant Bacillus megaterium strains isolated from Bhitarkanika mangrove soil and characterization of reduced product. Chemosphere 2011, 84, 1231-1237. [CrossRef]

76. Lampis, S.; Zonaro, E.; Bertolini, C.; Bernardi, P.; Butler, C.S.; Vallini, G. Delayed formation of zero-valent selenium nanoparticles by Bacillus mycoides SeiTE01 as a consequence of selenite reduction under aerobic conditions. Microb. Cell Fact. 2014, 13, 35-49. [CrossRef]

77. Shakibaie, M.; Khorramizadeh, M.R.; Faramarzi, M.A.; Sabzevari, O.; Shahverdi, A.R. Biosynthesis and recovery of selenium nanoparticles and the effects on matrix metalloproteinase-2 expression. Biotechnol. Appl. Biochem. 2010, 56, 7-15. [CrossRef] [PubMed]

78. Wang, T.; Yang, L.; Zhang, B.; Liu, J. Extracellular biosynthesis and transformation of selenium nanoparticles and application in $\mathrm{H}_{2} \mathrm{O}_{2}$ biosensor. Colloids Surf. B Biointerfaces 2010, 80, 94-102. [CrossRef] [PubMed]

79. Eszenyi, P.; Sztrik, A.; Babka, B.; Prokisch, J. Production of Lactomicrosel ${ }^{\circledR}$ and nanosize (100-500 nm) selenium spheres by probiotic lactic acid bacteria. Int. Conf. Food Eng. Biotechnol. 2011, 9, 97-101.

80. Shoeibi, S.; Mashreghi, M. Biosynthesis of selenium nanoparticles using Enterococcus faecalis and evaluation of their antibacterial activities. J. Trace Elem. Med. Biol. 2017, 39, 135-139. [CrossRef]

81. Rajasree, R.S.R.; Gayathri, S. Extracellular biosynthesis of Selenium nanoparticles using some species of Lactobacillus. Indian J. Geo Mar. Sci. 2015, 43, 766-775.

82. Moreno-Martin, G.; Pescuma, M.; Pérez-Corona, T.; Mozzi, F.; Madrid, Y. Determination of size and mass-and number-based concentration of biogenic SeNPs synthesized by lactic acid bacteria by using a multimethod approach. Anal. Chim. Acta 2017, 992, 34-41. [CrossRef]

83. Yazdi, M.H.; Mahdavi, M.; Setayesh, N.; Esfandyar, M.; Shahverdi, A.R. Selenium nanoparticle-enriched Lactobacillus brevis causes more efficient immune responses in vivo and reduces the liver metastasis in metastatic form of mouse breast cancer. DARU J. Pharm. Sci. 2013, 21, 33. [CrossRef] [PubMed]

84. Xu, C.; Qiao, L.; Guo, Y.; Ma, L.; Cheng, Y. Preparation, characteristics and antioxidant activity of polysaccharides and proteinscapped selenium nanoparticles synthesized by Lactobacillus casei ATCC 393. Carbohydr. Polym. 2018, 195, 576-585. [CrossRef] [PubMed]

85. Li, D.B.; Cheng, Y.Y.; Wu, C.; Li, W.W.; Li, N.; Yang, Z.C.; Tong, Z.H.; Yu, H.Q. Selenite reduction by Shewanella oneidensis MR-1 is mediated by fumarate reductase in periplasm. Sci. Rep. 2014, 4, 3735. [CrossRef] [PubMed]

86. Van Fleet-Stalder, V.; Chasteen, T.G.; Pickering, I.J.; George, G.N.; Prince, R.C. Fate of selenate and selenite metabolized by Rhodobacter sphaeroides. Appl. Environ. Microbiol. 2000, 66, 4849-4853. [CrossRef]

87. Wells, M.; McGarry, J.; Gaye, M.M.; Basu, P.; Oremland, R.S.; Stolz, J.F. Respiratory selenite reductase from Bacillus selenitireducens strain MLS10. J. Bacteriol. 2019, 201, e00614-18. [CrossRef] [PubMed]

88. Tugarova, A.V.; Kamnev, A.A. Proteins in microbial synthesis of selenium nanoparticles. Talanta 2017, 174, 539-547. [CrossRef] 
89. Wadhwani, S.A.; Shedbalkar, U.U.; Singh, R.; Chopade, B.A. Biogenic selenium nanoparticles: Current status and future prospects. Appl. Microbiol. Biotechnol. 2016, 100, 2555-2566. [CrossRef]

90. Tan, Y.; Wang, Y.; Wang, Y.; Xu, D.; Huang, Y.; Wang, D.; Wang, G.; Rensing, C.; Zheng, S. Novel mechanisms of selenate and selenite reduction in the obligate aerobic bacterium Comamonas testosteroni S44. J. Hazard. Mater. 2018, 359, 129-138. [CrossRef]

91. Nancharaiah, Y.V.; Lens, P.N.L. Selenium biomineralization for biotechnological applications. Trends Biotechnol. 2015, 33, 323-330. [CrossRef]

92. Bébien, M.; Kirsch, J.; Méjean, V.; Verméglio, A. Involvement of a putative molybdenum enzyme in the reduction of selenate by Escherichia coli. Microbiology 2002, 148, 3865-3872. [CrossRef]

93. Ridley, H.; Watts, C.A.; Richardson, D.J.; Butler, C.S. Resolution of distinct membrane-bound enzymes from Enterobacter cloacae SLD1a-1 that are responsible for selective reduction of nitrate and selenate oxyanions. Appl. Environ. Microbiol. 2006, 72, 5173-5180. [CrossRef] [PubMed]

94. Schröder, I.; Rech, S.; Krafft, T.; Macy, J.M. Purification and characterization of the selenate reductase from Thauera selenatis. J. Biol. Chem. 1997, 272, 23765-23768. [CrossRef]

95. Dridge, E.J.; Watts, C.A.; Jepson, B.J.N.; Line, K.; Santini, J.M.; Richardson, D.J.; Butler, C.S. Investigation of the redox centres of periplasmic selenate reductase from Thauera selenatis by EPR spectroscopy. Biochem. J. 2007, 408, 19-28. [CrossRef] [PubMed]

96. Krafft, T.; Bowen, A.; Theis, F.; Macy, J.M. Cloning and sequencing of the genes encoding the periplasmic-cytochrome b-containing selenate reductase of Thauera selenatis. DNA Seq. 2000, 10, 365-377. [CrossRef] [PubMed]

97. Lowe, E.C.; Bydder, S.; Hartshorne, R.S.; Tape, H.L.U.; Dridge, E.J.; Debieux, C.M.; Paszkiewicz, K.; Singleton, I.; Lewis, R.J.; Santini, J.M.; et al. Quinol-cytochrome c oxidoreductase and cytochrome c4 mediate electron transfer during selenate respiration in Thauera selenatis. J. Biol. Chem. 2010, 285, 18433-18442. [CrossRef]

98. Watts, C.A.; Ridley, H.; Condie, K.L.; Leaver, J.T.; Richardson, D.J.; Butler, C.S. Selenate reduction by Enterobacter cloacae SLD1a-1 is catalysed by a molybdenum-dependent membrane-bound enzyme that is distinct from the membrane-bound nitrate reductase. FEMS Microbiol. Lett. 2003, 228, 273-279. [CrossRef]

99. Ma, J.; Kobayashi, D.Y.; Yee, N. Chemical kinetic and molecular genetic study of selenium oxyanion reduction by Enterobacter cloacae SLD1a-1. Environ. Sci. Technol. 2007, 41, 7795-7801. [CrossRef]

100. Kuroda, M.; Yamashita, M.; Miwa, E.; Imao, K.; Fujimoto, N.; Ono, H.; Nagano, K.; Sei, K.; Ike, M. Molecular cloning and characterization of the srdBCA operon, encoding the respiratory selenate reductase complex, from the selenate-reducing bacterium Bacillus selenatarsenatis SF-1. J. Bacteriol. 2011, 193, 2141-2148. [CrossRef]

101. Butler, C.S.; Debieux, C.M.; Dridge, E.J.; Splatt, P.; Wright, M. Biomineralization of selenium by the selenate-respiring bacterium Thauera selenatis. Biochem. Soc. Trans. 2012, 40, 1239-1243. [CrossRef]

102. Yee, N.; Ma, J.; Dalia, A.; Boonfueng, T.; Kobayashi, D.Y. Se(VI) reduction and the precipitation of Se(0) by the facultative bacterium Enterobacter cloacae SLD1a-1 are regulated by FNR. Appl. Environ. Microbiol. 2007, 73, 1914-1920. [CrossRef] [PubMed]

103. Ma, J.; Kobayashi, D.Y.; Yee, N. Role of menaquinone biosynthesis genes in selenate reduction by Enterobacter cloacae SLD1a-1 and Escherichia coli K12. Environ. Microbiol. 2009, 11, 149-158. [CrossRef]

104. Guymer, D.; Maillard, J.; Sargent, F. A genetic analysis of in vivo selenate reduction by Salmonella enterica serovar Typhimurium LT2 and Escherichia coli K12. Arch. Microbiol. 2009, 191, 519-528. [CrossRef] [PubMed]

105. DeMoll-Decker, H.; Macy, J.M. The periplasmic nitrite reductase of Thauera selenatis may catalyze the reduction of selenite to elemental selenium. Arch. Microbiol. 1993, 160, 241-247. [CrossRef]

106. Basaglia, M.; Toffanin, A.; Baldan, E.; Bottegal, M.; Shapleigh, J.P.; Casella, S. Selenite-reducing capacity of the copper-containing nitrite reductase of Rhizobium sullae. FEMS Microbiol. Lett. 2007, 269, 124-130. [CrossRef] [PubMed]

107. Song, D.; Li, X.; Cheng, Y.; Xiao, X.; Lu, Z.; Wang, Y.; Wang, F. Aerobic biogenesis of selenium nanoparticles by Enterobacter cloacae Z0206 as a consequence of fumarate reductase mediated selenite reduction. Sci. Rep. 2017, 7, 3239. [CrossRef] [PubMed]

108. Painter, E.P. The chemistry and toxicity of selenium compounds, with special reference to the selenium problem. Chem. Rev. 1941, 28, 179-213. [CrossRef]

109. Kessi, J.; Hanselmann, K.W. Similarities between the abiotic reduction of selenite with glutathione and the dissimilatory reaction mediated by Rhodospirillum rubrum and Escherichia coli. J. Biol. Chem. 2004, 279, 50662-50669. [CrossRef]

110. Ni, T.W.; Staicu, L.C.; Nemeth, R.S.; Schwartz, C.L.; Crawford, D.; Seligman, J.D.; Hunter, W.J.; Pilon-Smits, E.A.H.; Ackerson, C.J. Progress toward clonable inorganic nanoparticles. Nanoscale 2015, 7, 17320-17327. [CrossRef]

111. Dungan, R.S.; Frankenberger, W.T. Reduction of selenite to elemental selenium by Enterobacter cloacae SLD1a-1. J. Environ. Qual. 1998, 27, 1301-1306. [CrossRef]

112. Xia, X.; Wu, S.; Li, N.; Wang, D.; Zheng, S.; Wang, G. Novel bacterial selenite reductase CsrF responsible for Se(IV) and Cr(VI) reduction that produces nanoparticles in Alishewanella sp. WH16-1. J. Hazard. Mater. 2018, 342, 499-509. [CrossRef] [PubMed]

113. Garbisu, C.; Carlson, D.; Adamkiewicz, M.; Yee, B.C.; Wong, J.H.; Resto, E.; Leighton, T.; Buchanan, B.B. Morphological and biochemical responses of Bacillus subtilis to selenite stress. BioFactors 1999, 10, 311-319. [CrossRef]

114. Zonaro, E.; Piacenza, E.; Presentato, A.; Monti, F.; Dell'Anna, R.; Lampis, S.; Vallini, G. Ochrobactrum sp. MPV1 from a dump of roasted pyrites can be exploited as bacterial catalyst for the biogenesis of selenium and tellurium nanoparticles. Microb. Cell Fact. 2017, 16, 215. [CrossRef]

115. Hunter, W.J. Pseudomonas seleniipraecipitans proteins potentially involved in selenite reduction. Curr. Microbiol. 2014, 69, 69-74. [CrossRef] 
116. Bebien, M.; Chauvin, J.P.; Adriano, J.M.; Grosse, S.; Verméglio, A. Effect of selenite on growth and protein synthesis in the phototrophic bacterium Rhodobacter sphaeroides. Appl. Environ. Microbiol. 2001, 67, 4440-4447. [CrossRef] [PubMed]

117. Ledgham, F.; Quest, B.; Vallaeys, T.; Mergeay, M.; Covès, J. A probable link between the DedA protein and resistance to selenite. Res. Microbiol. 2005, 156, 367-374. [CrossRef]

118. Gaballa, A.; Newton, G.L.; Antelmann, H.; Parsonage, D.; Upton, H.; Rawat, M.; Claiborne, A.; Fahey, R.C.; Helmann, J.D. Biosynthesis and functions of bacillithiol, a major low-molecular-weight thiol in Bacilli. Proc. Natl. Acad. Sci. USA 2010, 107, 6482-6486. [CrossRef] [PubMed]

119. Yuan, P.; Ding, X.; Yang, Y.Y.; Xu, Q.H. Metal nanoparticles for diagnosis and therapy of bacterial infection. Adv. Healthc. Mater. 2018, 7, 1701392. [CrossRef] [PubMed]

120. Zannoni, D.; Borsetti, F.; Harrison, J.J.; Turner, R.J. The bacterial response to the chalcogen metalloids Se and Te. Adv. Microb. Physiol. 2007, 53, 1-312. [CrossRef]

121. Helmann, J.D. Bacillithiol, a new player in bacterial redox homeostasis. Antioxid. Redox Signal. 2011, 15, 123-133. [CrossRef]

122. Nancharaiah, Y.V.; Lens, P.N.L. Ecology and biotechnology of selenium-respiring bacteria. Microbiol. Mol. Biol. Rev. 2015, 79, 61-80. [CrossRef]

123. Jain, R.; Jordan, N.; Weiss, S.; Foerstendorf, H.; Heim, K.; Kacker, R.; Hübner, R.; Kramer, H.; van Hullebusch, E.D.; Farges, F.; et al. Extracellular polymeric substances govern the surface charge of biogenic elemental selenium nanoparticles. Environ. Sci. Technol. 2015, 49, 1713-1720. [CrossRef]

124. Lenz, M.; Kolvenbach, B.; Gygax, B.; Moes, S.; Corvini, P.F.X. Shedding light on selenium biomineralization: Proteins associated with bionanominerals. Appl. Environ. Microbiol. 2011, 77, 4676-4680. [CrossRef] [PubMed]

125. Kamnev, A.A.; Dyatlova, Y.A.; Kenzhegulov, O.A.; Vladimirova, A.A.; Mamchenkova, P.V.; Tugarova, A.V. Fourier transform infrared (FTIR) spectroscopic analyses of microbiological samples and biogenic selenium nanoparticles of microbial origin: Sample preparation effects. Molecules 2021, 26, 1146. [CrossRef]

126. Tugarova, A.V.; Mamchenkova, P.V.; Dyatlova, Y.A.; Kamnev, A.A. FTIR and Raman spectroscopic studies of selenium nanoparticles synthesised by the bacterium Azospirillum thiophilum. Spectrochim. Acta A Mol. Biomol. Spectrosc. 2018, 192, 458-463. [CrossRef]

127. Sinharoy, A.; Saikia, S.; Pakshirajan, K. Biological removal of selenite from wastewater and recovery as selenium nanoparticles using inverse fluidized bed bioreactor. J. Water Process Eng. 2019, 32, 100988. [CrossRef]

128. Chandramohan, S.; Sundar, K.; Muthukumaran, A. Reducing agents influence the shapes of selenium nanoparticles (SeNPs) and subsequently their antibacterial and antioxidant activity. Mater. Res. Express 2019, 6, 0850i2. [CrossRef]

129. Rangrazi, A.; Bagheri, H.; Ghazvini, K.; Boruziniat, A.; Darroudi, M. Synthesis and antibacterial activity of colloidal selenium nanoparticles in chitosan solution: A new antibacterial agent. Mater. Res. Express 2019, 6, 1250h3. [CrossRef]

130. Chung, Y.C.; Su, Y.P.; Chen, C.C.; Jia, G.; Wang, H.L.; Wu, J.C.G.; Lin, J.G. Relationship between antibacterial activity of chitosan and surface characteristics of cell wall. Acta Pharmacol. Sin. 2004, 25, 932-936.

131. Slavin, Y.N.; Asnis, J.; Häfeli, U.O.; Bach, H. Metal nanoparticles: Understanding the mechanisms behind antibacterial activity. J. Nanobiotechnol. 2017, 15. [CrossRef]

132. Gottenbos, B.; Grijpma, D.W.; Van Der Mei, H.C.; Feijen, J.; Busscher, H.J. Antimicrobial effects of positively charged surfaces on adhering Gram-positive and Gram-negative bacteria. J. Antimicrob. Chemother. 2001, 48, 7-13. [CrossRef]

133. Dickson, J.S.; Koohmaraie, M. Cell surface charge characteristics and their relationship to bacterial attachment to meat surfaces. Appl. Environ. Microbiol. 1989, 55, 832-836. [CrossRef]

134. Tran, P.A.; O’Brien-Simpson, N.; Reynolds, E.C.; Pantarat, N.; Biswas, D.P.; O'Connor, A.J. Low cytotoxic trace element selenium nanoparticles and their differential antimicrobial properties against S. aureus and E. coli. Nanotechnology 2015, 27,045101 [CrossRef]

135. Boroumand, S.; Safari, M.; Shaabani, E.; Shirzad, M.; Faridi-Majidi, R. Selenium nanoparticles: Synthesis, characterization and study of their cytotoxicity, antioxidant and antibacterial activity. Mater. Res. Express 2019, 6, 0850d8. [CrossRef]

136. Galić, E.; Ilić, K.; Hartl, S.; Tetyczka, C.; Kasemets, K.; Kurvet, I.; Milić, M.; Barbir, R.; Pem, B.; Erceg, I.; et al. Impact of surface functionalization on the toxicity and antimicrobial effects of selenium nanoparticles considering different routes of entry. Food Chem. Toxicol. 2020, 144, 111621. [CrossRef]

137. Filipović, N.; Ušjak, D.; Milenković, M.T.; Zheng, K.; Liverani, L.; Boccaccini, A.R.; Stevanović, M.M. Comparative study of the antimicrobial activity of selenium nanoparticles with different surface chemistry and structure. Front. Bioeng. Biotechnol. 2021, 8, 624621. [CrossRef]

138. Tran, P.A.; Webster, T.J. Selenium nanoparticles inhibit Staphylococcus aureus growth. Int. J. Nanomed. 2011, 6, 1553-1558. [CrossRef]

139. Huang, T.; Holden, J.A.; Heath, D.E.; O’Brien-Simpson, N.M.; O'Connor, A.J. Engineering highly effective antimicrobial selenium nanoparticles through control of particle size. Nanoscale 2019, 11, 14937-14951. [CrossRef]

140. Srivastava, N.; Mukhopadhyay, M. Green synthesis and structural characterization of selenium nanoparticles and assessment of their antimicrobial property. Bioprocess Biosyst. Eng. 2015, 38, 1723-1730. [CrossRef]

141. Decuzzi, P.; Pasqualini, R.; Arap, W.; Ferrari, M. Intravascular delivery of particulate systems: Does geometry really matter? Pharm. Res. 2009, 26, 235-243. [CrossRef] 
142. Presentato, A.; Piacenza, E.; Anikovskiy, M.; Cappelletti, M.; Zannoni, D.; Turner, R.J. Biosynthesis of selenium-nanoparticles and nanorods as a product of selenite bioconversion by the aerobic bacterium Rhodococcus aetherivorans BCP1. New Biotechnol. 2018, 41, 1-8. [CrossRef]

143. Guisbiers, G.; Wang, Q.; Khachatryan, E.; Mimun, L.C.; Mendoza-Cruz, R.; Larese-Casanova, P.; Webster, T.J.; Nash, K.L. Inhibition of E. coli and S. aureus with selenium nanoparticles synthesized by pulsed laser ablation in deionized water. Int. J. Nanomed. 2016, 11,3731-3736. [CrossRef]

144. Wang, L.; Hu, C.; Shao, L. The antimicrobial activity of nanoparticles: Present situation and prospects for the future. Int. J. Nanomed. 2017, 12, 1227-1249. [CrossRef]

145. Calvo, J.; Martínez-Martínez, L. Mecanismos de acción de los antimicrobianos. Enferm. Infecc. Microbiol. Clín. 2009, $27,44-52$. [CrossRef] [PubMed]

146. Bruslind, L. General Microbiology; Oregon State University: Corvallis, OR, USA, 2017.

147. Gopinath, V.; Priyadarshini, S.; Loke, M.F.; Arunkumar, J.; Marsili, E.; MubarakAli, D.; Velusamy, P.; Vadivelu, J. Biogenic synthesis, characterization of antibacterial silver nanoparticles and its cell cytotoxicity. Arab. J. Chem. 2017, 10, 1107-1117. [CrossRef]

148. Fu, H.; Yuan, J.; Gao, H. Microbial oxidative stress response: Novel insights from environmental facultative anaerobic bacteria. Arch. Biochem. Biophys. 2015, 584, 28-35. [CrossRef]

149. Skalickova, S.; Milosavljevic, V.; Cihalova, K.; Horky, P.; Richtera, L.; Adam, V. Selenium nanoparticles as a nutritional supplement. Nutrition 2017, 33, 83-90. [CrossRef]

150. Johnson, L.A.; Hug, L.A. Distribution of reactive oxygen species defense mechanisms across domain bacteria. Free Radic. Biol. Med. 2019, 140, 93-102. [CrossRef] 